\title{
What Do Alternative Sanctions Mean?
}

\author{
Dan M. Kahan $\dagger$
}

Imprisonment is the punishment of choice in American jurisdictions. ${ }^{1}$ In everyday life, the modes of human suffering are numerous and diverse: when we lose our property, we experience need; when we are denounced by those whose opinions we respect, we feel shame; when our bodies are tormented, we suffer physical pain. But for those who commit serious criminal offenses, the law strongly prefers one form of suffering-the deprivation of liberty-to the near exclusion of all others. Some alternatives to imprisonment, such as corporal punishment, are barely conceivable. Others, including fines and community service, do exist but are used sparingly and with great reluctance. ${ }^{2}$

$\dagger$ Assistant Professor of Law, The University of Chicago. (C 1996 Dan M. Kahan. I am grateful to the Russell J. Parsons Fund for Faculty Research at the University of Chicago Law School for financial support; to Bruce Ackerman, Albert Alschuler, Mary Becker, Ruth Chang, Richard Craswell, David Currie, Richard Epstein, Elizabeth Garrett, Richard Helmholz, Stephen Holmes, Lawrence Lessig, John Lott, Tracey Meares, Bernard Meltzer, Norval Morris, Martha Nussbaum, Wiktor Osiatynski, Richard Posner, Richard Pildes, Stephen Schulhofer, David Strauss, and Cass Sunstein for comments; to participants in a workshop at the University of Chicago Law School for helpful suggestions; and to Sally Abrahamson and Richard De Liberty for research assistance.

1 See Bureau of Justice Statistics, Felony Sentences in State Courts, 1992 table 2 (Jan 1995) (70 percent of convicted felons sentenced to incarceration, 30 percent to probation).

2 See id at table 12 (18 percent of convicted felons fined, 6 percent sentenced to community service); Bureau of Justice Statistics, Sourcebook of Criminal Justice Statistics 464-65 table 5.29 (US GPO 1994) ("1994 Statistics") (fines imposed as sole punishment in only 1 percent of federal fraud cases, 1 percent of federal embezzlement cases, and 7 percent of federal criminal cases overall) (1994 data). A fine is more likely to be used as a supplement to imprisonment, and community service as a supplement to probation, than either is to be used as a substitute for imprisonment. See, for example, Sally T. Hillsman, Joyce L. Sichel, and Barry Mahoney, Fines in Sentencing: A Study of the Use of the Fine as a Criminal Sanction 162-63 (Vera Institute 1984) (fines); Franklin E. Zimring and Gordon Hawkins, The Scale of Imprisonment 183 (Chicago 1991) (community service). Capital punishment is another sparingly used alternative to imprisonment. Indeed, to describe capital punishment as an alternative to imprisonment seems odd. It is a widely shared conviction that capital punishment is appropriate only for a limited number of serious offenses and that it is inappropriate for a wide range of other offenses typically punished by imprisonment. In fact, capital punishment for offenses other than homicide is (for the time being) foreclosed by constitutional doctrine. See Coker $v$ Georgia, 433 US 584, 598 (1977). For these reasons, I will not address capital punishment in this Article. However, the sensibility that some forms of affiction are intrinsically inappropriate for certain types of offenses-a sensibility that is familiar in debates about capital punish- 
The singularity of American criminal punishments has been widely lamented. Imprisonment is harsh and degrading for offenders and extraordinarily expensive for society. Nor is there any evidence that imprisonment is more effective than its rivals in deterring various crimes. For these reasons, theorists of widely divergent orientations-from economics-minded conservatives to reform-minded civil libertarians-are united in their support for alternative sanctions. ${ }^{3}$

The problem is that there is no political constituency for such reform. If anything, the public's commitment to imprisonment has intensified in step with the theorists' disaffection with it. In the last decade, prison sentences have been both dramatically lengthened for many offenses and extended to others that have traditionally been punished only with fines and probation. ${ }^{4}$

What accounts for the resistance to alternative sanctions? The conventional answer is a failure of democratic politics. Members of the public are ignorant of the availability and feasibility of alternative sanctions; as a result, they are easy prey for self-interested politicians, who exploit their fear of crime by advocating more severe prison sentences. ${ }^{5}$ The only possible solution, on this analysis, is a relentless effort to educate the public on the virtues of the prison's rivals.

I want to advance a different explanation. The political unacceptability of alternative sanctions, I will argue, reflects their inadequacy along the expressive dimension of punishment. The public rejects the alternatives not because they perceive that these punishments won't work or aren't severe enough, but because they fail to express condemnation as dramatically and unequivocally as imprisonment.

ment-will be prominent in my discussion.

${ }^{3}$ See, for example, Richard A. Posner, Optimal Sentences for White-Collar Criminals, 17 Am Crim L Rev 409 (1980); Norval Morris and Michael Tonry, Between Prison and Probation: Intermediate Punishments in a Rational Sentencing System (Oxford 1990).

4 See, for example, William Tucker, Three Strikes and You're Dead, Am Spectator 22 (Mar 1994) (describing movement toward mandatory life imprisonment for repeat violent offenders); United States Sentencing Commission, Supplemental Report on the Initial Sentencing Guidelines and Policy Statements 18 (US GPO 1988) (explaining policy of increasing prison terms for white-collar offenders).

5 See Michael Tonry, Intermediate Sanctions in Sentencing Reform, 2 U Chi L Sch Roundtable 391, 404 (1995) (attributing the predominance of prison sentences to "partisan and ideological politics" and ill-conceived public "commitment to just deserts' rationales for punishment"); John R. Lott, Jr., Should the Wealthy Be Able to "Buy Justice"?, $95 \mathrm{~J}$ Pol Econ 1307, 1312 (1987) (attributing unnecessary use of imprisonment for white-collar offenders to "high cost" of "informing" electorate that short terms of imprisonment or fines are sufficient). 
This claim challenges the central theoretical premise of the case for alternative sanctions: that all forms of punishment are interchangeable along the dimension of severity or "bite." The purpose of imprisonment, on this account, is to make offenders suffer. The threat of such discomfort is intended to deter criminality, and the imposition of it to afford a criminal his just deserts. But liberty deprivation, the critics point out, is not the only way to make criminals uncomfortable. On this account, it should be possible to translate any particular term of imprisonment into an alternative sanction that imposes an equal amount of suffering. The alternatives, moreover, should be preferred whenever they can feasibly be imposed and whenever they cost less than the equivalent term of imprisonment. ${ }^{6}$

This account is defective because it ignores what different forms of affliction mean. Punishment is not just a way to make offenders suffer; it is a special social convention that signifies moral condemnation. Not all modes of imposing suffering express condemnation or express it in the same way. The message of condemnation is very clear when society deprives an offender of his liberty. But when it merely fines him for the same act, the message is likely to be different: you may do what you have done, but you must pay for the privilege. Because community service penalties involve activities that conventionally entitle people to respect and admiration, they also fail to express condemnation in an unambiguous way. This mismatch between the suffering that a sanction imposes and the meaning that it has for society is what makes alternative sanctions politically unacceptable.

The importance of the expressive dimension of punishment should be evident. It reveals, for one thing, that punishment reformers face certain objective constraints. The social norms that determine what different forms of suffering mean cannot be simply dismissed as the product of ignorance or bias; rather, they reflect deeply rooted public understandings that mere exhortation is unlikely to change. But there are also more hopeful implications. If we can understand the expressive dimension of punishment, we should be able to perceive not only what kinds of punishment reforms won't work but also which ones will. Careful attention to social norms might allow us to translate alternative sanctions into a punitive vocabulary that makes them a meaningful substitute for imprisonment.

6 See, for example, Posner, 17 Am Crim L Rev at 410-11 (cited in note 3); Morris and Tonry, Between Prison and Probation at 89-90 (cited in note 3). 
My argument will unfold in three parts. In Part I, I examine the expressive dimension of punishment. There I attempt to make concrete the idea that punishment is usefully conceived of as a language. $I$ also consider the connection between this conception of punishment and conventional accounts of deterrence and retribution.

Part II shows how social meaning objectively constrains the political acceptability of alternative sanctions. Just as the speaker of a real language can't hope to be understood if she uses words in an idiosyncratic way, so those who wish to reform a punishment regime can't hope to make their proposals acceptable if they advocate forms of affliction that don't express condemnation. By analyzing public reactions to corporal punishment, community service, and fines, I try to identify the social norms that make imprisonment express condemnation and its rivals express something else.

Finally, Part III examines how the meaning of alternative sanctions can be reformed. Shaming penalties unambiguously express condemnation and are a feasible alternative to imprisonment for many offenses. Moreover, the conventional alternatives to imprisonment can be made politically acceptable, I will argue, if they are combined with shaming penalties or are recast to impose shame themselves.

\section{The Expressive Dimension of Punishment}

Does it make sense to conceive of punishment as a language? Many observers in many different places and at many different times have concluded that it does. Durkheim seems to have had this idea in mind, for example, when he characterized punishment as a "sign indicating [ ] the sentiments of the collectivity," as did Hegel, when he described it as the "annul[ment of a] crime, which otherwise would have been held valid." James Fitzjames Stephen, the nineteenth-century English political theorist and judge, understood punishment to be the means by which "law gives definite expression and a solemn ratification ... to the hatred which is excited by the commission of an offence...."

7 Emile Durkheim, The Division of Labor in Society 63 (Free Press 1984) (W.D. Halls, trans).

${ }^{8}$ Hegel's Philosophy of Right $\S 99$ at 69 (Oxford 1952) (T.M. Knox, trans). Or at least Hegel is so understood in David E. Cooper, Hegel's Theory of Punishment, in Z.A. Pelczynski, ed, Hegel's Political Philosophy: Problems and Perspectives 151 (Cambridge 1971).

James Fitzjames Stephen, 2 A History of the Criminal Law of England 81 
Various contemporary philosophers, including Jean Hampton, ${ }^{10}$ Joel Feinberg, ${ }^{11}$ and Robert Nozick, ${ }^{12}$ have also emphasized the expressive dimension of punishment.

But theirs is not the orthodox view. "Deterrence" and "retributivism" dominate mainstream theorizing. The proponents of these accounts frequently deride the expressive theory or, even more contemptuously, ignore it altogether. ${ }^{13}$

Disrespect for the expressive theory can be attributed to two causes. The first is its obscurity. The writings of Hegel and Durkheim are filled with dense abstractions, like "annulment," "negation," and "collective conscience." Contemporary philosophers, while more precise in their terminology, still fail to connect their accounts to actual institutions and practices. ${ }^{14}$

Focusing on the abstract quality of such theorizing, critics assail the expressive position as either incoherent or dexivative. Crimes, as historical events, are not genuinely "annulled" or "negated" by punishment, they point out. ${ }^{15}$ And if expression of condemnation were the salient ingredient of punishment, why wouldn't society be content simply to criticize the criminal verbally? ${ }^{16}$ Maybe annulment can be understood less literally as a "righting of the moral balance" upset by the criminal's acts; and maybe expression of disapproval through hard treatment can be defended as discouraging criminality. But if this is how we must reformulate the expressive theorists' arguments, then their ac-

(Macmillan 1883).

${ }_{10}$ See Jean Hampton, The retributive idea, in Jeffrie G. Murphy and Jean Hampton, Forgiveness and Mercy 111, 125 (Cambridge 1988) ("${ }^{2}[R]$ etributive punishment . . . symbolizes the correct relative value of wrongdoer and victim."); Jean Hampton, An Expressive Theory of Retribution, in Wesley Cragg, ed, Retributivism and Its Critics 1 (Steiner 1992).

11 See Joel Feinberg, The Expressive Function of Punishment, reprinted in Joel Feinberg, Doing and Deserving: Essays in the Theory of Responsibility 95 (Princeton 1970).

12 See Robert Nozick, Philosophical Explanations 370-74 (Harvard 1981).

${ }^{13}$ See Ted Honderich, Punishment: The Supposed Justifications 34 (Hutchinson 1969) (describing Hegel's position as a "theory of very secondary interest"); Nigel Walker, Punishment, danger and stigma: The morality of criminal justice 24-25 (Basil Blackwell 1980) (complaining that it is difficult to find "critical and thorough discussions of the concept [of expressive denunciation]").

14 For an illuminating exception, see Samuel H. Pillsbury, Evil and the Law of Murder, 24 UC Davis L Rev 437 (1990), which uses expressive arguments to explain and critique murder gradations.

${ }_{15}$ See Stanley I. Benn and Richard S. Peters, Social Principles and the Democratic State 177 (Allen \& Unwin 1959); Honderich, Punishment at 45 (cited in note 13); C.L. Ten, Crime, Guilt, and Punishment 38-39 (Oxford 1987).

${ }^{16}$ See H.L.A. Hart, Law, Liberty, and Morality 65-66 (Stanford 1963); Benn and Peters, Social Principles at 177-78 (cited in note 15); Ten, Crime, Guilt, and Punishment at 40-41, 45 (cited in note 15); Walker, Punishment, danger and stigma at 32-33 (cited in note 13). 
count dissolves into conventional retributive and deterrence theories and thus need not be independently taken into account. ${ }^{17}$ Or so it is claimed.

The second difficulty for the expressive theory is that it appears strikingly illiberal. Deterrence justifies punishment to prevent harm to others; retributivism confines it to those who voluntarily choose to inflict such harm. The expressive theory, by contrast, appears to emphasize neither consequences nor choices, but rather the enforcement of society's moral values. In his famous rejoinder to Lord Devlin, who had used the expressive theory to criticize proposals to decriminalize homosexuality, H.L.A. Hart assailed this justification for punishment as "belong[ing] to the prehistory of morality."18 "The idea that we may punish offenders against a moral code, not to prevent harm or suffering or even the repetition of the offence but simply as a means of venting or emphatically expressing moral condemnation, is uncomfortably close to human sacrifice as an expression of religious worship."19

I believe that the conventional disregard for the expressive view is ill-considered. The expressive theory, properly understood, is less imperial than the conventional deterrence and retributive theories; it doesn't purport to explain everything of significance in criminal law and may, in fact, be constrained by other important considerations. Nonetheless, theorizing that excludes the expressive dimension of punishment generates incomplete explanations of what the criminal law is and unreliable prescriptions of what it should be.

That is what I will try to show; but what I offer in this Part is only a first step. I will set forth a conception of the expressive theory in simple and concise terms. Although this exposition might at least suggest why the charges typically made against

${ }^{17}$ See, for example, Hart, Law, Liberty, and Morality at 66 (cited in note 16) (arguing that expressive condemnation dissolves into consequentialism); Michael S. Moore, The moral worth of retribution, in Ferdinand Schoeman, ed, Responsibility, Character, and the Emotions: New Essays in Moral Psychology 179, 181 (Oxford 1987) (arguing that expressive theory is in fact utilitarian); Ten, Crime, Guilt, and Punishment at 45-46, 51-52 (cited in note 15) (arguing that expressive theories are merely forms of utilitarianism); Walker, Punishment, danger and stigma at 28-30 (cited in note 13) (noting difficulty of disentangling expressive theory from utilitarianism and retributivism). To the extent that the expressive theory is defended on consequentialist grounds, moreover, it stands in need of empirical support. See H.L.A. Hart, Social Solidarity and the Enforcement of Morality, 35

U Chi L Rev 1, 5-8 (1967).

${ }_{18}$ Hart, Law, Liberty, and Morality at 83 (cited in note 16).

19 Id at 65-66. 
this account are inadequate, I don't intend my discussion to be a complete theoretical defense of the expressive position. Indeed, I want to defend the expressive view without recourse to deep theorizing. I will ultimately seek to demonstrate the utility of the expressive view not by establishing its conceptual coherence in the abstract, but rather by using it-in Parts II and III-to account for public sensibilities and to identify desirable institutional reforms.

\section{A. What Punishment Says and How}

Actions have meanings as well as consequences. ${ }^{20}$ Part of being rational consists in selecting actions that, against the background of social norms, express meanings appropriate to our purposes and goals. Along some dimension, for example, five thousand dollars might be equivalent in value to everything I would do with and for a friend during a certain period of time. But if my goal is to be her friend, then giving her the money and sharing my time with her are not interchangeable; giving money in lieu of time fails to convey the respect and affection that being a good friend requires.

This is a general account of expressive rationality; ${ }^{21}$ the expressive theory of punishment can be viewed as a special instance of this account. Under this view, we can give a satisfactory account of crime and punishment only if we pay close attention to their social meaning.

The distinctive meaning of criminal wrongdoing is its denial of some important value, such as the victim's moral worth. ${ }^{22}$ Along one dimension-say, personal wealth - theft might hurt a person as much as being outperformed by a business competitor. The reason that theft but not competition is a crime, on this account, ${ }^{23}$ is that against the background of social norms theft ex-

20 See generally Lawrence Lessig, The Regulation of Social Meaning, $62 \mathrm{U}$ Chi L Rev 943 (1995).

21 See generally Elizabeth Anderson, Value in Ethics and Economics 17-43 (Harvard 1993). For expressive accounts of law, see Richard H. Pildes, The Unintended Cultural Consequences of Public Policy, 89 Mich L Rev 936 (1991); Cass R. Sunstein, On the Expressive Function of Law, $144 \mathrm{U} \mathrm{Pa} \mathrm{L}$ Rev (forthcoming 1996).

22 See Jeffrie G. Murphy, Forgiveness and resentment, in Jeffrie G. Murphy and Jean Hampton, Forgiveness and Mercy 14, 25 (Cambridge 1988); Jean Hampton, Forgiveness, resentment, and hatred, in Jeffrie G. Murphy and Jean Hampton, Forgiveness and Mercy 35, 43-45 (Cambridge 1988).

${ }_{23}$ But not on others. See Richard A. Posner, An Economic Theory of the Criminal Law, 85 Colum L Rev 1193, 1195-96 (1985) (claiming that behavior is deemed criminal when it transfers a good coercively and bypasses an available market). My claim is not 
presses disrespect for the injured party's worth, whereas competition (at least ordinarily) does not. In effect, the thief's behavior says to the victim, "you matter so little, relative to me, that I can take your property without your consent." The theory of meaning here, moreover, is objective: so long as we understand his act to be theft, the wrongdoer's behavior conveys disrespect for the victim regardless of whether the thief meant to make any particular statement. ${ }^{25}$

The expressive theory also explains the relative seriousness of different forms of wrongdoing. A rape, for example, is often more reprehensible than an ordinary assault-even if the assault results in greater physical injury-because the violation of a woman's sexual autonomy conveys greater disrespect for her worth than do most other violations of her person. Or compare the actions of a white supremacist who kills an African-American out of racial hatred and a mother who in anger kills a man who has sexually abused her child. Both acts are wrong, and their consequences are in some sense equivalent-there is one dead person in each case. Nevertheless, the racist's killing is more worthy of condemnation precisely because his hatred expresses a more reprehensible valuation than does the mother's anger. ${ }^{26}$

Under the expressive view, the signification of punishment is moral condemnation. By imposing the proper form and degree of affliction on the wrongdoer, society says, in effect, that the offender's assessment of whose interests count is wrong. ${ }^{27}$ It follows, moreover, that when society deliberately forgoes answering the wrongdoer through punishment, it risks being perceived as endorsing his valuations; hence the complaint that unduly lenient punishment reveals that the victim is worthless in the eyes of the law. ${ }^{28}$

that the expressive view alone explains these phenomena.

24 See Hampton, Expressive Theory of Retribution at 6 (cited in note 10).

25 See Cooper, Hegel's Theory of Punishment at 166 (cited in note 8).

${ }^{26}$ See Dan M. Kahan and Martha C. Nussbaum, Two Conceptions of Emotion in Criminal Law, 96 Colum L Rev 269, 353 (1996). Again, the expressive account is not the only one. See id at 305-12, 323-24 (examining consequentialist and voluntarist accounts of homicide gradations). An imaginative person will be able to explain any feature of criminal law using whatever abstract theory she likes. Compare Jon Elster, Nuts and Bolts for the Social Sciences 8 (Cambridge 1989) ("With some ingenuity-and many scholars have a great deal-one can always tell a story in which [particular rules or practices are optimal].") (emphasis in original). Thus, the choice among such theories must depend on something other than how well they fit basic legal phenomena.

${ }^{27}$ See Hampton, The retributive idea at 130-31 (cited in note 10); Nozick, Philosophical Explanations at 370-76 (cited in note 12).

${ }^{28}$ See, for example, Christopher Kilbourne, Glen Ridge Terms: 15 Years; Convicts 
These considerations suggest at least one possible response to the charge that the expressive theory is illiberal. The critics assert that the expressive view is dangerous because it concerns itself with values rather than with consequences and choices. A modest proponent of the expressive view might agree that it is inappropriate to punish values simpliciter, but still note the difficulty of identifying which choices and consequences to punish, and how much, if they are considered apart from the values that they express. As the rape and theft examples illustrate, attention to social meaning is ubiquitous in the definitions and gradations of criminal offenses. It would be a mistake, moreover, to think that no appropriately robust conception of liberalism can justify this central feature of the law. ${ }^{29}$

The contention that the expressive theory supports illiberal results is based on a specious form of generalization. Expressive arguments can be used to justify the criminalization of homosexuality, but the expressive theory entails neither this nor any other form of intolerance. Indeed, the expressive theory illuminates a critical part of what is wrong with such laws. The injustice of a prohibition on same-sex sodomy, for example, consists at least as much in the disrespect it expresses toward gays as it does in the impingement of anyone's liberty to engage in particular sexual acts. From an expressive point of view, hate crime legislation can be used to criticize the devaluation of gays just as effectively as sodomy laws can be used to entrench it.

The expressive theory also underscores the importance of form and convention in punishment. Military service might in some sense be equivalent to imprisonment if we consider their effects on a person's liberty. But the reason that only imprisonment and not conscription is regarded as punishment is that against the background of social norms only imprisonment expresses society's authoritative moral condemnation. ${ }^{30}$

Could Serve Less than 2, Record A1, A12 (Apr 24, 1993) (Bergen County, NJ) (reporting female observer's comment that lenient sentence of men convicted of raping retarded girl sends "[t]he clear message to women ... that the crime of rape is not a crime worthy of punishment. ... It's an outrage to women."); AP, Judge Draws Protests after Cutting Sentence of Gay Man's Killer, NY Times A15 (Aug 17, 1994) (reporting comment of gay activist that light sentence of man convicted of manslaughter for intentional killing of homosexual says "that it's O.K. to kill faggots"). See generally Kahan and Nussbaum, 96 Colum L Rev at 352 (cited in note 26).

${ }_{29}$ See Kahan and Nussbaum, 96 Colum L Rev at 360-62 (cited in note 26) (Appraising values expressed by offenders' emotions furthers the liberal goal of fostering public deliberation.).

${ }^{30}$ See Henry M. Hart, Jr., The Aims of the Criminal Law, 23 L \& Contemp Probs 
The formal and conventional underpinnings of what different forms of affliction signify constrain society's options for expressing condemnation. Just as it would be irrational for a person who wishes to express respect and affection for a friend to offer her money rather than shared experiences, so would it be irrational for society to attempt to condemn a wrongdoer by imposing an affliction that does not signify condemnation within that society. Punishment, as a language, has a vocabulary uniquely suited for getting its meaning across.

This point should emerge more completely in my examination of the political unacceptability of fines and community service; ${ }^{31}$ but it is useful at this stage to consider how it relates to another of the standard criticisms of the expressive theory-namely, that if punishment were genuinely expressive it would suffice to condemn a wrongdoer verbally. ${ }^{32}$ This argument disregards what convention and form contribute to meaning. In a certain community, the accepted way for a husband to show love and commitment to his wife on their twenty-fifth wedding anniversary might be to give her a ring (or some other gift); if so, just telling her that he feels such love and commitment wouldn't be sufficient to express his meaning against the background of this social norm. The question put by the conventional criticism of the expressive view, then, is whether social norms make words an adequate substitute for hard treatment in expressing condemnation.

The answer is obviously no. In some societies, and even in ours at an earlier time, ${ }^{33}$ public denunciation by itself might have been sufficient to convey condemnation of a wrongdoer, but such is clearly not true today. Imagine that a judge proposed only to denounce a brutal rapist rather than to sentence him to prison. ${ }^{34}$ Such a sentence would no doubt be regarded as inadequate for purposes of deterrence and retribution. But even beyond that, mere verbal denunciation would be understood to trivialize the offense: the way for society to show that it takes rape seriously, and to show that it genuinely condemns a particular rapist, is to

401, 404-05 (1958).

${ }^{31}$ See Parts II.B-C.

${ }^{32}$ See note 16 and accompanying text.

${ }_{33}$ See Adam J. Hirsch, The Rise of the Penitentiary: Prisons and Punishments in Early America 4-5, 38 (Yale 1992) (discussing use of "admonition" as criminal punishment in colonial America).

${ }^{34}$ Compare State $v$ Chaney, 477 P2d 441 (Alaska 1970) (criticizing imposition of minimum one-year sentence for rape with recommendation of immediate parole). 
make him suffer in an appropriate way. ${ }^{35}$ For inflicting punishment-as for many other purposes-actions speak louder than words.

\section{B. Expressive Condemnation vs. Retributivism and Deterrence}

According to its critics, the expressive theory can be saved from incoherence only at the expense of its analytical independence. Clarifying the theory inevitably merges the expressive account into deterrence or retributivism, making independent study of the expressive view unnecessary. ${ }^{36}$

A defender of the expressive theory might respond in one of two ways. First, she could attempt to develop an abstract conception of the expressive position that is in fact analytically independent of either deterrence or retributivism. She could then show that this account either is or should be the basis of criminal law. ${ }^{37}$ This strategy attacks the claim of derivativeness head-on.

A second strategy is less ambitious. It essentially demurs to the claim of analytical interdependence. It might be the case that any plausible conception of the expressive view can be fit into the framework of deterrence or retributivism, but it would be fallacious to conclude that the expressive theory can therefore be ignored; that conclusion would follow only if it were possible to develop plausible conceptions of deterrence and retributivism that make no reference to the expressive function of criminal law. And that, the defender of the expressive view would try to show, cannot be done.

I want to pursue this second strategy in the next part of this essay. To set it up, I will consider how retributivism and deterrence theories can be analytically related to and distinguished from the expressive theory.

Start with very basic conceptions of retributivism and deterrence. "Retributivism is the view that punishment is justified by the moral culpability of those who receive it. A retributivist pun-

${ }^{35}$ See id at 447 ("[T] $]$ he sentence imposed falls short of effectuating the goal of community condemnation, or the reaffirmation of societal norms for the purpose of maintaining respect for the norms themselves. ... [R]espect for society's condemnation of forcible rape ... is eroded and reaffirmation of these societal norms negated lby failure to sentence the defendant to a substantial term of imprisonment].").

${ }^{36}$ See text accompanying note 17.

37 Compare Nozick, Philosophical Explanations at 363-97 (cited in note 12) (arguing that a theory that punishment condemns false valuations depends on neither consequentialist nor voluntarist considerations.). 
ishes because, and only because, the offender deserves it.."38 Deterrence, in contrast, asserts that punishment is justified because it averts future harm. Society should punish, on this view, only if the expected benefits of a particular penalty exceed the expected costs of imposing it. ${ }^{39}$

The core idea of retributivism-that an individual should be punished "because, and only because, [he] deserves it" vague. It is possible to give content to this notion without reference to expressive condemnation; one might say, for example, that an individual deserves punishment when "he renounces a burden which others have voluntarily assumed and thus gains an advantage which others ... do not possess," ${ }^{31}$ or when human beings naturally intuit that the individual has engaged in "a wrong action [that] . . . calls for the infliction of suffering or deprivation on the agent." ${ }^{\prime 2}$ But it is also possible to use the expressive view to inform desert. On this account, an individual deserves punishment when he engages in behavior that conveys disrespect for important values. The proper retributive punishment is the one that appropriately expresses condemnation and reaffirms the values that the wrongdoer denies. ${ }^{43}$

The expressive theory can also be used to inform deterrence. One way in which it might do so is by supplying a consequentialist theory of value. Without a theory for identifying which outcomes are socially disvalued and how much, it is impossible to know what to deter or how to allocate limited punishment resources among different forms of wrongdoing. ${ }^{44}$ Again, one could attempt to specify a consequentialist theory of value-perhaps wealth-maximization ${ }^{45}$-that is indifferent to expressive sensibilities. Or one could overtly draw on these sensibilities to identify preferred outcomes. ${ }^{46}$ To return to an earlier example, one might conclude that a white man who kills an Afri-

${ }^{33}$ Moore, The moral worth of retribution at $\mathbf{1 7 9}$ (cited in note 17).

39 See, for example, Jeremy Bentham, An Introduction to the Principles of Morals and Legislation, in The Utilitarians 7, 162 (Doubleday 1961).

40 Moore, The moral worth of retribution at 179 (cited in note 17).

41 Herbert Morris, Persons and Punishment, in Jeffrie Murphy, ed, Punishment and Rehabilitation 40, 42 (Wadsworth 1973).

42 J.L. Mackie, Retributivism: A Test Case for Ethical Objectivity, in Joel Feinberg and Hyman Gross, eds, Philosophy of Law 677, 682 (Wadsworth 4th ed 1991).

${ }^{43}$ See generally Hampton, Expressive Theory of Retribution (cited in note 10).

4. See Kahan and Nussbaum, 96 Colum L Rev at 354-55 (cited in note 26).

45 See, for example, Posner, 85 Colum L Rev 1193 (cited in note 23).

46 See Anderson, Value in Ethics and Economics at 29-30 (cited in note 21) (arguing that states of affairs have value only by virtue of conformity to independent expressive norms); Kahan and Nussbaum, 96 Colum L Rev at 355 (cited in note 26). 
can-American out of racial hatred should be punished more severely than a woman who kills the abuser of her child in anger, even if equal punishment would maximize social wealth; when expressive considerations are taken into account, racist killings are deemed to harm society more than are impassioned killings of child molesters. ${ }^{47}$

Another way that the expressive theory might reinforce deterrence is through preference formation. The law can discourage criminality not just by "raising the cost" of such behavior through punishments, but also through instilling aversions to the kinds of behavior that the law prohibits. ${ }^{48}$ The latter is often referred to as the "moralizing" or "moral educative" effect of punishment. ${ }^{49}$

The moralizing effect of criminal law depends on a variety of mechanisms, all of which are reinforced by the expressive character of the law. The first is preference adaptation. ${ }^{50}$ To avoid cognitive dissonance, citizens form aversions to the kinds of behavior-whether rape, theft, or insider trading-that the law tells them are unworthy of being valued..$^{51}$ This sort of preference adaptation is most likely to take place when citizens perceive the law as expressing society's moral condemnation of such conduct. $^{52}$

47 For simplicity, this example assumes that one dollar of punishment buys the same amount of deterrence for each kind of offense.

18 See generally Kenneth G. Dau-Schmidt, An Economic Analysis of the Criminal Law as Preference-Shaping Policy, 1990 Duke L J 1; Ronald J. Rychlak, Society's Moral Right to Punish: A Further Exploration of the Denunciation Theory of Punishment, 65 Tulane $\mathrm{L}$ Rev 299, 332-37 (1990). For empirical assessments, see Leonard Berkowitz and Nigel Walker, Law and Moral Judgments, 30 Sociometry 410, 421-22 (1967); Nigel Walker and Michael Argyle, Does the Law Affect Moral Judgments?, 4 Brit J Criminol 570, 575 (1964); Nigel Walker and Catherine Marsh, Do Sentences Affect Public Disapproval?, 24 Brit J Criminol 27, 38-39 (1984).

49 See, for example, Johs Andenaes, General Prevention-Illusion or Reality?, $43 \mathrm{~J}$ Crim L Criminol \& Police Sci 176, 179 (1952); Jean Hampton, The Moral Education Theory of Punishment, 13 Phil \& Pub Aff 208 (1984); Gordon Hawkins, Punishment and Deterrence: The Educative, Moralizing, and Habituative Effects, 1969 Wis L Rev 550, 55360.

${ }^{50}$ See generally Jon Elster, Sour Grapes: Studies in the Subversion of Rationality 109-40 (Cambridge 1983); Cass R. Sunstein, Legal Interference with Private Preferences, 53 U Chi L Rev 1129, 1146-50 (1986).

s1 See Elliot Aronson and J. Merrill Carlsmith, Effect of Severity of Threat on the Devaluation of Forbidden Behavior, $66 \mathrm{~J}$ Abnormal \& Soc Psych 584 (1963); Johannes Andenaes, The General Preventive Effects of Punishment, 114 U Pa L Rev 949, 978 (1966).

52 See Bentham, Principles of Morals and Legislation at $339 \mathrm{n} 181$ (cited in note 39) ("A punishment may be said to be calculated to answer the purpose of a moral lesson, when, by reason of the ignominy it stamps upon the offence, it is calculated to inspire the public with sentiments of aversion towards those pernicious habits and dispositions with which the offence appears to be connected; and thereby to inculcate the opposite beneficial habits and dispositions."). 
The law also moralizes by shaping relevant "belief-dependent" preferences. ${ }^{53}$ Empirical studies show that the willingness of persons to obey various laws is endogenous to their beliefs about whether others view the law as worthy of obedience: if compliance is perceived to be widespread, persons generally desire to obey; but if they believe that disobedience is rampant, their commitment to following the law diminishes. ${ }^{54}$ Even a strong propensity to obey the law, in other words, can be undercut by a person's "desire not to be suckered." When the law effectively expresses condemnation of wrongdoers, however, it reassures citizens that society does indeed stand behind the values that the law embodies.

Finally, the law moralizes through goodwill. Individuals are more disposed to obey particular laws, whether or not those laws accord with their moral beliefs, when they perceive the criminal law as a whole to be basically just. ${ }^{56}$ They are more likely to have this perception when criminal punishment confirms, rather than disappoints, shared expectations about what behavior is worthy of moral condemnation. ${ }^{57}$

Theorists who dismiss the expressive theory can't draw on it to support retributivism or deterrence reasoning in any of these ways. Thus, the question should not be whether expressive condemnation can be successfully disconnected from deterrence and retribution, but whether it's possible to develop sensible conceptions of the latter theories without reference to the expressive view. I believe that it isn't; punishment theorizing that disregards the expressive view is necessarily incomplete. It is exactly this inattention to meaning, I will argue, that has blinded con-

${ }^{53}$ See generally Peter H. Huang and Ho-Mou Wu, More Order without More Law: $A$ Theory of Social Norms and Organizational Cultures, $10 \mathrm{~J} \mathrm{~L} \mathrm{Econ} \mathrm{\&} \mathrm{Org} 390$ (1994).

${ }_{54}$ See Harold G. Grasmick and Donald E. Green, Legal Punishment, Social Disapproval and Internalization as Inhibitors of Illegal Behavior, $71 \mathrm{~J}$ Crim L \& Criminol 325, 332-34 (1980) (finding positive correlation between disposition to obey the law and belief that peers obey); Berkowitz and Walker, 30 Sociometry at 421 (cited in note 48 ) (positive correlation between belief that illegal conduct is immoral and belief that peers view conduct as immoral); Walker and Argyle, 4 Brit $J$ Criminol at 577 (cited in note 48) (same). See also Jack P. Gibbs, Preventive Effects of Capital Punishment Other than Deterrence, 14 Crim L Bull 34, 41 (1978) ("Indeed, an individual is not likely to persist in the condemnation of some type of act if he or she observes that the act is committed openly and frequently with impunity.").

${ }_{55}$ Huang and $W u, 10 \mathrm{~J} \mathrm{~L}$ Econ \& Org at 403 (cited in note 53 ).

${ }_{56}$ See Tom R. Tyler, Why People Obey the Law 62 (Yale 1990).

${ }^{57}$ See id; Paul H. Robinson and John M. Darley, The Utility of Desert (on file with U Chi L Rev). 
ventional theorists to the political unacceptability of alternative sanctions.

\section{What ALternatrve SANCTIONS MEAN}

A decade of significant reform has not lessened the dependence of American jurisdictions on imprisonment. Indeed, many of the reforms-including the United States Sentencing Guidelines, ${ }^{58}$ mandatory minima for drug offenses, ${ }^{59}$ and the use of life sentences for repeat offenders ${ }^{60}$-have only deepened it. Other reforms have succeeded in enriching the menu of punishment options: "boot camps," "intensive probation supervision," "house arrest," and other new sanctions now complement the traditional array. But the public's enthusiasm for such innovations has proven ironically selective. The new alternatives, while growing in popularity, are being imposed almost entirely on offenders who otherwise would have received straight probation. ${ }^{61}$ The effect is that punishments have become only more severe and more costly, not less, as alternative sanctions have been added to the mix. ${ }^{62}$

Is the durability of imprisonment inevitable? Incarceration might be the only option for many violent offenses-including murder, forcible rape, and armed robbery. But offenders convicted of these crimes make up less than half the American prison population. The rest have engaged in nonviolent offenses-from

s8 See United States Sentencing Commission, Supplementary Report on the Initial Sentencing Guidelines and Policy Statements 18 (1987) (explaining decision of Sentencing Commission to require imprisonment of white-collar offenders traditionally punished only with fines and probation).

${ }^{59}$ See, for example, 21 USC \$§ 841(b), 844(a) (1994).

${ }^{\infty}$ See Tucker, Three Strikes and You're Dead, Am Spectator at 22 (cited in note 4).

61 See Doris Layton MacKenzie and Claire Souryal, $A$ "Machiavellian" Perspective on the Development of Boot Camp Prisons: A Debate, 2 U Chi L Sch Roundtable 435, 448-49 (1995); Dennis J. Palumbo, Mary Clifford, and Zoann K. Snyder-Joy, From Net Widening to Intermediate Sanctions: The Transformation of Alternatives to Incarceration From Benevolence to Malevolence, in James M. Byrne, Arthur J. Lurigio, and Joan Petersilia, eds, Smart Sentencing: The Emergence of Intermediate Sanctions 229 (Sage 1992); Tonry, $2 \mathrm{U}$ Chi L Sch Roundtable at 396-97 (cited in note 5).

62 It would be a gross error, however, to conclude that such sanctions have failed entirely to meet their intended purposes. They were in fact devised to be "intermediate" in severity relative to imprisonment and probation; insofar as their use has reduced the number of straight probation sentences, then, these punishments have successfully responded to the perception that probation is too lenient for many serious offenses. See Morris and Tonry, Between Prison and Probation at 3 (cited in note 3); Tonry, $2 \mathrm{U}$ Chi L Sch Roundtable at 394-95 (cited in note 5). I use the phrase "alternative sanctions" rather than "intermediate sanctions" to underscore that I am focusing only on the failure of such penalties to replace imprisonment. 
larceny, to fraud, to drug distribution, to drunk driving. ${ }^{63}$ Alternative sanctions would be both feasible and cost effective for many of these offenders, particularly those who are sentenced to relatively short terms of imprisonment. ${ }^{64}$ The extent of imprisonment in this country is not a matter of law-enforcement necessity; it's a result of political choice.

My aim in this Part is to show that the failure of alternative sanctions to displace imprisonment stems from their social meaning. I suggested in the last Part that punishment has an expressive dimension: it conveys a society's condemnation of the wrongdoer, and its reaffirmation of the values that his acts deny. It follows that afflictions that are equivalent to each other for some purposes-say, for inflicting suffering or for deterring future wrongdoing - can still vary in their effectiveness as punishments based on their expressive effects. This explains the uneven acceptance of alternative sanctions: they express condemnation more potently than probation, but much less potently than imprisonment.

I will focus primarily on fines and community service because those are the punishments that proponents of alternative sanctions typically advocate. I will start my analysis, however, by considering a sanction that critics of imprisonment are loath to defend: corporal punishment. Their reluctance is well founded, since corporal punishment has expressive connotations that make it a radically inadequate substitute for imprisonment. What the critics of imprisonment fail to realize, however, is that the deficiencies of corporal punishment generalize; understanding why corporal punishment fails to express appropriate condemnation reveals how social meaning constrains the political acceptability of conventional alternative sanctions.

63 Only 46.6 percent of the 704,181 persons incarcerated in state prisons (as of 1991), and only 22 percent of the 381,160 incarcerated in state jails (as of 1989), were serving time for violent offenses. See Bureau of Justice Statistics, Sourcebook of Criminal Justice Statistics 593 table 6.21, 613 table 6.42 (US GPO 1993). The percentages are even smaller for persons incarcerated in federal prisons, where nearly 60 percent of the inmates were serving time for drug offenses. See 1994 Statistics at 559 table 6.39 (cite in note 2) (1994 data).

${ }_{64}$ In state courts, the median term of incarceration for both property offenses and drug offenses is twenty-four months. See Bureau of Justice Statistics, Felony Sentences at table 3 (cited in note 1) (1992 data). In federal courts, the average sentence for property offenses is just under twenty months; the average drug possession sentence is just under twenty-two months. 1994 Statistics at 457 table 5.24 (cited in note 2) (preliminary 1992 data). 
Before I turn to this argument, let me make one methodological observation. My central claim-that we can gauge the political acceptability of alternative sanctions by considering whether they express appropriate condemnation-turns on the social meaning of different sanctions. I intend to treat social meaning as more or less a matter of fact. I thus draw liberally on media reports, op-ed pieces, and letters to the editor, as well as legislative histories and judicial opinions, not because I believe (necessarily) that the arguments made in them are persuasive, but because the sentiments they express provide evidence of how the public perceives alternative sanctions. To be sure, these sources are not, by themselves, definitive evidence of social meaning. I also draw, therefore, on empirical analyses of how the public interprets different afflictions. Nevertheless, much of my analysis remains impressionistic, and many of the claims that I make can and should be tested more rigorously. But since the political controversy surrounding society's commitment to imprisonment is immediate, the existing gap in empirical knowledge should not discourage informed speculation about how deep-seated public sensibilities shape the opportunities for reform.

\section{A. Corporal Punishment vs. Imprisonment}

No state currently authorizes corporal punishment for criminal offenders and it has been nearly a century and a half since a substantial number of them did. ${ }^{65}$ Nor is corporal punishment likely to make a comeback anytime soon. Proposals to punish certain offenses by whipping, caning, or paddling surface occasionally, but are invariably subject to ridicule and defeated in the political process.$^{66}$ The institution of corporal punishment, then,

6s See generally Harry Elmer Barnes, The Story of Punishment: A Record of Man's Inhumanity to Man 110-11 (Patterson Smith 2d ed 1972); Myra C. Glenn, Campaigns against Corporal Punishment: Prisoners, Sailors, Women, and Children in Antebellum America 128-47 (SUNY 1984). Approximately half the states, however, still authorize corporal punishment of children in public schools. See Scott Bloom, Comment, Spare the Rod, Spoil the Child? A Legal Framework for Recent Corporal Punishment Proposals, 25 Golden Gate U L Rev 361, 369 (1995).

${ }_{66}$ See Eric Bailey, Assembly Rejects Paddling as Punishment, LA Times A3 (Feb 1, 1996) (available in LEXIS); John DiStaso, Vandalism Bill Gets Tough on Convicted Minors, Manchester Union Leader 6 (Mar 8, 1996) (available in LEXIS) (reporting defeat of proposal for public spanking of juvenile vandals); text accompanying notes 100-04 (discussing defeat of proposals to reintroduce corporal punishment in aftermath of caning of Michael Fay). Individual judges occasionally impose corporal punishment on an ad hoc basis; when they do, their decisions usually provoke intense criticism. See, for example, AP, Tenn. Judge's Canings Called 'a Throwback', Commercial Appeal B2 (Sept 26, 1994) (Memphis, Tenn) (reporting community outrage over Tennessee judge's whipping of 
can fairly be described as extinct. It is instructive to try to figure out why.

One explanation-that corporal punishment is clearly unconstitutional-can be immediately dismissed. ${ }^{67}$ No court has ever held corporal punishment per se to be cruel and unusual. ${ }^{68}$ Indeed, as late as 1963, the Supreme Court of Delaware-the last state to abandon corporal punishment-rejected the argument that the Eighth Amendment prohibits whipping criminal offenders. $^{69}$ Justice Scalia publicly stated the same conclusion even more recently, although he allowed that the enactment of such legislation seems inconceivable. ${ }^{70}$ In any event, the notion that democratically elected representatives are deterred from enacting legislation by the prospect (much less the uncertain prospect) of constitutional invalidation is fairly naive. ${ }^{71}$

juvenile offenders); Stephen Robinson, Judge Takes Off His Belt for Beating in Court, Daily Telegraph 3 (Sept 23, 1995) (available in LEXIS) (reporting objections and potential disciplinary proceedings following South Carolina judge's directive that grandmother whip offender convicted of possessing crack cocaine); Jim Bebbington, Paddling Decision Whacked, Dayton Daily News $1 B$ (Feb 9, 1995) ("Domestic violence experts and others Wednesday criticized an agreement in which a Troy[, Ohio] man avoided prosecution for child abuse by allowing himself to be paddled by a police officer.").

${ }^{67}$ See generally Daniel E. Hall, When Caning Meets the Eighth Amendment: Whipping Offenders in the United States, 4 Widener J Pub L 403 (1995).

${ }_{68}$ In Weems $v$ United States, 217 US 349 (1910), the Supreme Court invalidated a fifteen-year prison sentence to be served cadena - that is, in chains-which was to be followed by the permanent deprivation of various property and civil rights. What made this sentence cruel and unusual in the Court's view was not merely the bodily torment of the cadena, but primarily the disproportionality of the punishment to the seriousness of the offense-a false claim for a trivial sum of money. Id at 380-81.

See State v Cannon, 55 Del 587, 190 A2d 514, 518-19 (1963). Delaware, the only twentieth-century holdout, abolished corporal punishment by statute in 1972 . See Reuters, Whipping Post Banned by New Delaware Law, NY Times Section 1 at 32 (July 9, 1972). Repeal provoked some controversy, albeit relatively little. See Dover Bureau, Whipping Amendment Defeated, Evening J 61 (May 19, 1972) (Wilmington, Del) (reporting only minor legislative opposition to abolition); Dover Bureau, Punishment Referendum Bid Whipped, Evening J 11 (June 23, 1972) (Wilmington, Del) (reporting defeat of measure to submit abolition issue to popular referendum); Editorial, New Criminal Code Now, Evening J 18 (May 20, 1972) (Wilmington, Del) (applauding abolition on ground that corporal punishment is contrary to "mores and standards of today's society"). An attempt to reintroduce corporal punishment in Delaware in 1989 fizzled out with virtually no political support. See Tom Troy, Castle Opposes Whipping Post, UPI Wire (Feb 7, 1989) (available in LEXIS) (reporting Delaware Governor Michael Castle's opposition to reintroduction of corporal punishment); Letter from Representative Michael N. Castle (Del) to Dan M. Kahan (Oct 12, 1995) (on file with U Chi L Rev) ("There have been discussions since [1972], on occasion, of 'bringing back the whipping post,' but none of these have been taken seriously; so no real opposition needed to be mounted in 1989 or at any other time since then.").

${ }^{70}$ See Justice Scalia Says Caning Likely Constitutional, SF Chronicle A18 (May 7, 1994).

${ }^{71}$ See generally Donald G. Morgan, Congress and the Constitution: A Study of Re- 
The idea that corporal punishment is extinct because no one believes it would work is also unpersuasive. ${ }^{72}$ There is at least a modest amount of empirical evidence that corporal punishment discourages various forms of criminality; there is no credible evidence that it is less effective in this respect than imprisonment. ${ }^{73}$ What is more, it is clear that corporal punishment-in the form of whipping, paddling, or nonlethal electric shock-would be cheaper to inflict than even short terms of imprisonment. ${ }^{74}$ From an optimal deterrence point of view, then, corporal punishment seems like an ideal alternative sanction.

Do retributivist considerations rule out corporal punishment? It seems strange to suggest that corporal punishment makes offenders suffer more pain than they deserve. When we total up the chronic pain and the repeated episodes of acute pain (from beatings or sexual assaults by other inmates, for example) typically associated with even short terms of incarceration, imprisonment is certain to rival or surpass corporal punishment in painfulness. ${ }^{75}$

It is sometimes suggested, more abstractly, that corporal punishment is inconsistent with individual dignity. This is an even more puzzling claim. To be sure, it is degrading to be whipped; but it is also degrading to be caged and subjected to the horrifying array of brutalities that make up prison life. ${ }^{76}$ How

sponsibility 335-39 (Belknap 1966) (noting propensity of legislators to enact legislation without regard to constitutionality).

${ }^{72}$ See, for example, Gallup/CNN/USA Today Poll (Apr 1994) (available in Westlaw, Poll Database) (finding that 63 percent of Americans believed that caning would effectively deter crime in the U.S.).

${ }^{73}$ See Graeme Newman, Just and Painful: A Case for the Corporal Punishment of Criminals 127-36 (Macmillan 1983). The low crime rates in nations that continue to use corporal punishment also furnish mildly probative evidence of the effectiveness of this mode of discipline. See, for example, Michael Elliott, Crime \& Punishment, Newsweek 18, 22 (Apr 18, 1994) (discussing low crime rate in Singapore).

${ }_{71}$ See Newman, Just and Painful at 5-6 (cited in note 73); Steven S. Kan, Corporal Punishments and Optimal Incapacitation, $25 \mathrm{~J}$ Legal Stud 121 (1996).

${ }^{75}$ See Newman, Just and Painful at 15-16 (cited in note 73). The incidence of sexual assault and other forms of prison violence is extraordinarily high, even in low- and medium-security institutions. See, for example, the collection of statistics in Lee $\mathrm{H}$. Bowker, Prison Victimization 26 (Elsevier 1980) (77.6 percent of North Carolina inmates report being victims of assault.); id at 23 (murder rate of 617 per 100,000 prisoners in Tennessee, compared with rate of 11 per 100,000 statewide); Cindy Struckman-Johnson, et al, Sexual Coercion Reported by Men and Women in Prison, $33 \mathrm{~J}$ Sex Res (forthcoming 1996) (At least 9 percent of male inmates in low-security and 22 percent in high-security Nebraska prisons report having been sexually assaulted.); Wayne S. Wooden and Jay Parker, Men Behind Bars: Sexual Exploitation in Prison 18 (Plenum 1982) (study finding that 14 percent of male inmates in medium-security California prison report having been sexually assaulted).

${ }^{76}$ See Farmer v Brennan, 114 S Ct 1970, 1987 (1994) (Blackmun concurring): 
can we tell which experience offends individual dignity more? Shouldn't we ask the affected individuals? If we did, we would probably discover that most offenders would prefer corporal punishment to imprisonment. ${ }^{77}$ If the goal is to respect "individual dignity," why second-guess offenders about what course of action treats them with the most respect?

Another possibility is that corporal punishment-however effective, and whatever its relationship to individual desert-degrades society. Norval Morris and Michael Tonry, leading defenders of alternative sanctions, reject corporal punishments out of hand on the ground that they are "brutalizing, not only to those who suffer such punishments but ... to the society that imposes them." ${ }^{\text {78 }}$ To some, this claim might seem as paradoxical as the assertion that corporal punishment offends individual dignity. How can it be that corporal punishment brutalizes us more than imprisonment, which we know is just as painful, just as undignified, just as violent, and almost certainly more destructive of the offender's personality?

Under conventional deterrence and retributivist theories, then, it is difficult to explain why the American public resists corporal punishment. The problem, though, lies not with public attitudes but with the theories that have been used to assess them. The deterrence and retributivist arguments that I have considered so far disregard the expressive function of criminal law. Once the expressive dimension is brought into focus, it is much easier to make sense of the claims that corporal punishment violates individual dignity and degrades society. For in light of its history, corporal punishment is freighted with social meanings that make it a manifestly inadequate substitute for imprisonment as a means of expressing appropriate moral condemnation.

The horrors experienced by many young inmates, particularly those who... are convicted of nonviolent offenses, border on the unimaginable. Prison rape not only threatens the lives of those who fall prey to their aggressors, but is potentially devastating to the human spirit. Shame, depression, and a shattering loss of self-esteem, accompany the perpetual terror the victim thereafter must endure.... Although formally sentenced to a term of incarceration, many inmates discover that their punishment, even for nonviolent offenses like credit card fraud or tax evasion, degenerates into a reign of terror unmitigated by the protection supposedly afforded by prison officials.

77 See, for example, Bebbington, Paddling Decision Whacked, Dayton Daily News at 1B (cited in note 66).

${ }_{78}$ Morris and Tonry, Between Prison and Probation at 6 (cited in note 3). 
In colonial America, corporal punishment was the dominant penalty for noncapital offenses. The inventory of such penalties was richly stocked, from the pillory, to the whipping post, to the ducking stool. Moreover, corporal punishment was highly ceremonial. It was always inflicted in public, and the public often participated in its administration. ${ }^{79}$

The abolition of corporal punishment (which occurred solely as a result of political reform, not constitutional litigation) was animated by two changes in social conditions that radically altered perceptions of this mode of discipline. The first was the loosening of the tight communal bonds that characterized colonial life. For early Americans, shame was an even more salient ingredient of corporal punishment than was physical pain. "The sting of the lash and the contortions of the stocks were surely no balm, but even worse for community members were the piercing stares of neighbors who witnessed their disgrace and with whom they would continue to live and work. ${ }^{180}$ But as American communities grew and became more impersonal, the disgrace of corporal punishment receded: "[c]ertainly, the threat of a session on the pillory was less daunting when performed before persons with whom offenders were unacquainted, and with whom they need have no further personal contact." ${ }^{\prime 11}$ As a result, corporal punishment itself "seemed less meaningful"; ${ }^{22}$ in a society of strangers, the bare deprivation of status no longer resonated as a symbol of the community's moral disapproval. ${ }^{83}$

The second change was the democratizing of American society. The Revolution unleashed a passion for equality that impelled Americans to root out all perceived vestiges of social hierarchy from within their basic institutions and laws. ${ }^{84}$ Corporal

79 "It was the common practice of malevolent individuals to throw stale eggs, decomposed vegetables, dead animals, filth from the streets, as well as dangerous missiles of every description, at the unfortunate victims of the stocks or pillory." Herbert Arnold Falk, Corporal Punishment: A Social Interpretation of its Theory and Practice in the Schools of the United States 27 (Columbia 1941). See also Gordon S. Wood, The Radicalism of the American Revolution 72-73 (Vintage 1991).

so Hirsch, Rise of the Penitentiary at 34 (cited in note 33).

81 Id at 38.

82 Wood, Radicalism at 193 (cited in note 79).

83 See Michael Stephen Hindus, Prison and Plantation: Crime, Justice, and Authority in Massachusetts and South Carolina, 1767-1878 100 (North Carolina 1980) (describing decline of public corporal punishment in "the increasingly anonymous and transient world" of postrevolutionary Massachusetts).

\& See generally Wood, Radicalism (cited in note 79). Of course, their perception of what counted as social hierarchy was itself lamentably partial. See Thurgood Marshall, Reflections on the Bicentennial of the United States Constitution, $101 \mathrm{Harv}$ L Rev 1, 2 
punishment was targeted for reform because it was perceived to be distinctive of hierarchical relationships; the infliction of acute physical pain was the way that sovereigns disciplined their subjects, husbands their wives, parents their children, and masters their servants or slaves. ${ }^{85}$ As such, it rankled Americans' republican sensibilities for states to use this same mode of discipline to punish citizens, even the errant ones who committed crimes. ${ }^{86}$ As one nineteenth-century reformex explained:

[T]he fact is that we, citizens of the Republic, feel that certain domestic brutalities are the children of monarchies and despotisms; that they were produced by superstition, ignorance, and savagery; and that they are not in accord with the free and superb spirit that founded and preserves the Great Republic. ${ }^{87}$

Corporal punishment, then, was unacceptable not just because it no longer expressed condemnation in a society that had lost its communal intimacy, but because it now expressed hierarchy in a society characterized by egalitarian mores. ${ }^{88}$

Imprisonment became the dominant form of punishment by the middle of the nineteenth century. The rise of the penitentiary was the product of many causes, including, at least for a time,

(1987).

${ }_{85}^{85}$ See Lawrence M. Friedman, Crime and Punishment in American History 74 (BasicBooks 1993); Glenn, Campaigns against Corporal Punishment at 55-56 (cited in note 65); Falk, Corporal Punishment at 14-15, 108 (cited in note 79). Indeed, under English law, "gentlemen, unlike commoners, did not have their ears cropped or their bodies flogged." Wood, Radicalism at 29 (cited in note 79).

${ }^{86}$ See Friedman, Crime and Punishment at 74 (cited in note 85) ("Somehow whipping was ... unrepublican. It was an offense to the citizen's dignity."); Glenn, Campaigns against Corporal Punishment at 56 (cited in note 65) ("Although convicts were certainly not free men, prison reformers believed that the latter's discipline should reflect the republican principles of the nation as much as possible."). See also Falk, Corporal Punishment at 108 (cited in note 79) ("[C]orporal punishment is rooted in a fixed order of society, based on the principle of authoritarianism.").

87 Robert G. Ingersoll, Is Corporal Punishment Degrading?, in 6 The Works of Robert G. Ingersoll 503 (Dresden 1909).

${ }_{88}$ The association of bodily torment with the monarchy also animated penal reform in France. See Michel Foucault, Discipline and Punish: The Birth of the Prison 47-53, 79-82 (Pantheon 1977). By contrast, corporal punishment persisted in Great Britain-a relatively aristocratic society-until the middle of the twentieth century. Indeed, public opinion polls suggest that a substantial majority of English citizens may actually favor its reintroduction. See Anna Blundy, Blow for Justice?, Guardian 15 (Apr 19, 1994) (Manchester, England). See also James O. Midgley, Corporal Punishment and Penal Policy: Notes on the Continued Use of Corporal Punishment with Reference to South Africa, 73 J Crim L \& Criminol 388 (1982) (noting Conservative Party's support for corporal punishment in the 1979 general election). 
the ideal of rehabilitation. But one of the earliest and most persistent impetuses for this mode of discipline was the perception that it was superior to corporal punishment as a means of expressing appropriate moral condemnation. ${ }^{89}$

The dissipation of community life in early America was accompanied by growing devotion to individual liberty. Accordingly, the threat of liberty deprivation seemed a natural replacement for the threat of status deprivation formerly associated with corporal punishment. ${ }^{90}$ Moreover, because liberty was so intensely and universally valued, imprisonment was an effective instrument for conveying public condemnation and inducing shame even in a society of strangers. Early prisons were thus structured to maximize the public humiliation of offenders, who were "put [ ] on display as if in a zoo."

Proponents of imprisonment also defended this institution as "more suited to the genius of a republic." They viewed liberty deprivation as a mode of discipline naturally suited to an egalitarian social order; imprisonment expressed what citizens of a republic shared-their liberty-rather than what set the punisher and the punished apart. ${ }^{93}$

The expressive dimension of punishment also explains nineteenth-century Americans' perceptions of the relationship between corporal punishment, imprisonment, and slavery. Ab-

29 Imprisonment appealed to Jacksonian-era Americans because incarceration was thought to separate the offender from corrupting social influences and to furmish society a chance to reform him. See generally David J. Rothman, The Discovery of the Asylum: Social Order and Disorder in the New Republic 57-108 (Little Brown 1990). Nevertheless, even after it became clear by the middle of the century that imprisonment was ill suited to rehabilitation, Americans clung to it out of revulsion toward corporal punishment. See David J. Rothman, Conscience and Convenience: The Asylum and its Alternatives in Progressive America 28-29 (HarperCollins 1980).

${ }_{90}$ See Friedman, Crime and Punishment at 77 (cited in note 85); Hirsch, Rise of the Penitentiary at 53, 75-76 (cited in note 33). As the prominent Quaker philanthropist and penitentiary advocate Benjamin Rush put it: "Personal liberty is so dear to all men, that the loss of it, for an indefinite time, is a punishment so severe, that death has often been preferred to it." Benjamin Rush, An Enquiry into the Effects of Public Punishments upon Criminals and upon Society 19 (1787), quoted in Hirsch, Rise of the Penitentiary at $177 \mathrm{n}$ 56.

${ }^{91}$ Hindus, Prison and Plantation at 101 (cited in note 83); see also Friedman, Crime and Punishment at 77 (cited in note 85) (noting that Pennsylvania Constitution of 1776 expressly required that "the public, 'at proper times' ... be 'admitted to see the prisoners at their labour'").

${ }^{92}$ Governor's Message, 1792-93 Mass Acts 694 (Jan 30, 1793), quoted in Hirsch, Rise of the Penitentiary at 50 (cited in note 33 ).

${ }_{93}$ Just as the prison was perceived to underscore commitment to social equality in America, so the guillotine was understood to embody equality in France. See Foucault, Discipline and Punish at 12-13 (cited in note 88). 
stracted from historical context, corporal punishment and slavery do not seem inextricably connected. But in the minds of many nineteenth-century Americans, corporal punishment was unambiguously "slavish." 94 This was so not just because Southern owners beat their slaves but because corporal punishment was conventionally associated with all manner of social hierarchy, of which the master-slave relationship was merely the most extreme. ${ }^{95}$ Viewed abstractly, imprisonment, which was routinely accompanied by forced labor, could have been thought to bear an unmistakable resemblance to slavery. Yet this idea barely occurred to nineteenth-century Americans precisely because to them liberty deprivation was the right way to discipline the free citizens of a republic. ${ }^{96}$ There was, in fact, extensive overlap in membership in the movements to abolish slavery, eliminate corporal punishment, and institute penitentiaries. ${ }^{97}$

These reactions to corporal punishment and imprisonment were widespread but not universal within American society. The significations of these forms of affliction were the product of particular social conditions and, to the extent that those conditions varied, so too did the meaning of these sanctions. In the South, for example, where hierarchical social relations and traditional conceptions of honor retained their hold, corporal punishment was viewed as relatively unproblematic and persisted in some states until the eve of the Civil War. ${ }^{98}$ The legitimacy of corporal punishment provoked sectional divisions that were nearly as intense as-indeed, that were inextricably bound up with-sectional divisions over slavery. ${ }^{99}$

94 Glenn, Campaigns against Corporal Punishment at 57 (cited in note 65) (quoting various sources).

${ }_{95}$ See Friedman, Crime and Punishment at 74 (cited in note 85); Falk, Corporal Punishment at 14-15 (cited in note 79).

96 See Hirsch, Rise of the Penitentiary at 75-84 (cited in note 33).

${ }^{97}$ See id at 76-77; Glenn, Campaigns against Corporal Punishment at 112-14 (cited in note 65).

${ }^{98}$ See Hindus, Prison and Plantation at 101 (cited in note 83):

In South Carolina, at least, these punishments seemed entirely compatible with the state's concern for honor. All the reasons that made these punishments less attractive in Massachusetts simply were not operative in South Carolina, a relatively stable rural state where face-to-face contact remained important and where honor was accorded great protection.

99 See Glenn, Campaigns Against Corporal Punishment at 112-14 (cited in note 65) (describing sectional divisiveness that characterized congressional debates during the 1840 s and 1850s over use of corporal punishment in the Navy). 
So far, I have looked at the decline of corporal punishment from a purely historical vantage point. Do the expressive sensibilities that promoted the nineteenth-century shift from this mode of affliction to imprisonment have anything to do with the political unacceptability of corporal punishment today? They clearly do. In particular, the association of corporal punishment with social hierarchy persists. In the aftermath of the caning of Michael Fay-the American teenager convicted of vandalism in Singapore-lawmakers in a handful of states and municipalities introduced measures to restore corporal punishment. ${ }^{100}$ All of these proposals were defeated, and the recurring theme-from Massachusetts to Mississippi to California-was that corporal punishment is an unacceptable reminder of America's history of slavery and racial inequality:

[T]he bloody past has not yet receded far enough for public whippings to be a viable option.... For too many here, the mental picture of a caning in the courthouse square resonates too closely with the cultural memory of the runaway slave led shackled back to the plantation and given 40 lashes as an example. ${ }^{101}$

${ }^{100}$ See Ed Anderson, Paddling Bill Is Trounced, Times-Picayune B1 (June 25, 1994) (available in LEXIS) (Louisiana); Ann Bancroft, Panel Rejects Plan to Paddle Graffiti Artists, SF Chronicle A19 (Aug 11, 1994) (California); Reed Branson, Lawmakers Put off Vote on Bill to Require Caning, Commercial Appeal A13 (Mar 15, 1995) (Tennessee); Jìm Yardley, Caning Bill Killed in Miss. Senate, Times-Picayune B9 (Feb 26, 1995) (available in LEXIS) (Mississippi); Reuters, Caning for Vandals Proposed in St. Louis, NY Times Section 1 at 8 (May 21, 1994) (St. Louis, Mo); Richard Stewart, New Law with Sting Sought: Paddling for Graffiti, Houston Chronicle A20 (July 29, 1994) (San Antonio, Tex); Terry M. Neal, Sting of Friend's Death Prompts a Caning Bill in Maryland, Wash Post B1 (Mar 12, 1995) (Maryland); Kendall Anderson, Backers of Paddling Want Teen Offenders to Feel the Pain, Dallas Morning News 1A (June 6, 1994) (various jurisdictions).

${ }^{101}$ Larry Copeland, Movement for Caning in US Beginning to be Taken Seriously, Houston Chronicle A20 (Mar 12, 1995) (available in LEXIS). See also Paddling Instead of Prison: Some States Considering It, Charleston Daily Mail 7A (Feb 8, 1995) (available in LEXIS) (Opponents "believe it is . . . uncomfortably reminiscent of the whippings doled out to slaves and the beatings endured by civil rights demonstrators."); Editorial, Flogging Justice, Boston Globe 14 (Feb 23, 1995) (corporal punishment invokes brutal image of racism and slavery); Editorial, Singapore, USA?, USA Today 10A (Feb 9, 1995) (criticizing proposals on the ground they are "particularly painful to descendants of slaves," who "remember all too vividly the abuses corporal punishment bred in the name of justice"); Editorial, Whipping, Caning Can't Be the Best Solution to Crime, News \& Record A15 (Mar 16, 1995) (Greensboro, NC) (available in LEXIS) (Corporal punishment is inextricably connected to "our shameful history of slavery-when floggings were routine."); Eric Bailey, Paddling Bill Puts Conroy in Hot Seat of National Debate, LA Times A1, A12 (June 23, 1994) (quoting opponent as ridiculing corporal punishment proposal as work of "Neanderthal lawmakers who want to go back to the days of the slave owners"); Larry Copeland, Public Likes Proposed Public-Beating Laws; Experts Do Not, Sunday Gazette 
Opponents also effectively discredited corporal punishment by connecting it to authoritarian political regimes. ${ }^{102}$ Thus, for a decided majority of Americans, corporal punishment remains politically unacceptable because it continues to say the wrong thing about the relationship between citizens and the state. ${ }^{103}$

Mail 5A (Mar 12, 1995) (Charleston, NC) (available in LEXIS) (quoting political scientist in Atlanta: "In the South, this just brings back all those memories dating back to the plantation and slavery days, through the $1930 \mathrm{~s}$, ' $40 \mathrm{~s}$, and '50s and lynchings, all the way up through the old chain gangs. . . It just carries with it that kind of stigma."); Editorial, Cane-mania, Balt Sun 12A (Feb 22, 1995) (available in LEXIS) (criticizing proposal as racially divisive); Ann O'Hanlon, New Interest in Corporal Punishment, Wash Post A21 (Mar 5, 1995) (For Mississippi opponents "the hidden message of corporal punishment is racism."); Paddling Bill Defeated in Assembly, UPI Wire (Aug 10, 1994) (available in LEXIS) ("[A]n angry Assemblywoman Barbara Lee, D-Oakland, compared the measure to the lynching of blacks in the South.").

${ }_{102}$ See, for example, Lisa Lapin, Paddling Proposed for Taggers, Fresno Bee A1 (June 29 , 1994) (available in LEXIS) (quoting opponent of state corporal punishment proposal: "We're going to join countries like Iran and Saudi Arabia if we add this punishment to our repertoire."); Andrew B. Schmookler, Must We Employ Barbarism to Contain Barbarism?, Balt Sun 27A (Apr 29, 1994) ("Why are citizens of this free and democratic country looking admiringly at repressive dictatorships like Singapore and Saudi Arabia?"); Angelo Funicelli, Letter to the Editor, LA Times B6 (May 19, 1994) ("Leave it to an Orange County Republican to turn to a fascist nation as a model for American justice. May I ask why [Assemblyman] Conroy did not turn to the democracy of Switzerland to find out how they manage to keep their streets spotless without beating people bloody? Or to the open societies of the Netherlands or Denmark for their secrets in keeping incidents of violent crime lower than Singapore's?"); Editorial, Time to Assert American Values, NY Times A20 (Apr 13, 1994) (linking corporal punishment to collectivist ideology that allows "governments from China to Indonesia [to] rationalize abuses" carried out by "the political elite"); Lawmakers Promoting Proposals on Paddling, News \& Record A1 (May 29, 1994) (Greensboro, NC) (available in LEXIS) (quoting corporal punishment opponent: "[paddling is] not appropriate in this democracy"); AP, California Paddle Plan Strikes Out, Rocky Mountain News 40A (May 19, 1994) (Sacramento, Cal) (quoting mayor opposed to public spanking of convicted juvenile offenders: 'We don't take care of those kinds of issues in this society that way"); Marilyn B. Allen, Letter to Editor, LAA Times B6 (May 13, 1994) (ridiculing ,emulation of Singapore, where "robotized citizens ... aren't even allowed to think"). Compare Robert Reno, Caning Our Youth Is a Whacky Way to Teach a Lesson, Newsday A57 (May 27, 1994) ("That the idea of caning youthful offenders in America should be born of a practice originally instituted by insufferable British colonial administrators to maintain order among their non-white subjects is, to say the least, weird."). The use of corporal punishment for criminal offenders in fact remains confined almost exclusively to nondemocratic regimes in Asia and the Middle East. See generally Tom Kuntz, Beyond Singapore: Corporal Punishment, A to $Z$, NY Times E5 (June 26, 1994). Although this theme does not expressly figure in public debate, the association of corporal punishment with hierarchy is also likely reinforced by the continued use of this mode of discipline for school children. See text accompanying notes 65 .

${ }^{103}$ Public opinion polls at around the time of the Michael Fay incident showed that, although a substantial percentage of Americans approved of Singapore's decision to punish Fay consistently with its own laws, a substantial majority opposed the reintroduction of corporal punishment in the United States. See Ronald Brownstein, Singapore's Caning Sentence Divides Americans, Poll Finds, LA Times A20 (Apr 21, 1994) (finding that Americans approved of Singapore's caning of Fay by margin of 49 percent to 48 
Whether corporal punishment fails to express moral condemnation, however, is a closer question. Because there is such overwhelming consensus on the value of liberty in our society-and so little consensus, relatively speaking, on anything else-liberty deprivation remains a tremendously potent symbol for expressing public condemnation. But is it really the case that imprisonment alone has this power? Contemporary advocates of corporal punishment propose that it be inflicted in a form likely to humiliate offenders. ${ }^{104}$ Opponents of corporal punishment do not seem to contest that it would have this effect; it is enough for them that any element of shaming associated with this mode of affliction would be fatally tainted by connotations of inequality.

But whatever weight one assigns to these respective objections to corporal punishment, the demise of this mode of discipline powerfully illustrates the significance of the expressive dimension of punishment. Corporal punishment was and is likely to remain politically unacceptable for expressive reasons. At one point in history, many Americans came to view corporal punishment as lacking the power to convey something true-that offenders warrant moral condemnation. To this day, many Americans view corporal punishment as inappropriate because it also conveys something false-that offenders are the natural or social inferiors of those who discipline them. These significations-not the perceived deficiencies of corporal punishment from a narrow deterrence or retributivist point of view-are what made Americans turn to imprisonment, which, against the background of egalitarian social norms, expresses condemnation both potently and appropriately. These lessons are vital to understanding the political unacceptability of fines and community service.

\section{B. Fines vs. Imprisonment}

Fines are the most commonly defended alternative sanction. Proponents make an optimal-deterrence argument: fines are comparably effective to imprisonment, and enrich rather than

percent, but that 60 percent opposed the use of caning in the United States); Elliot, Crime, Newsweek at 19 (cited in note 73) (Americans oppose use of corporal punishment in United States 52 percent to 38 percent); Time/CNN Poll (Apr 11, 1994) (disapprove of caning in United States by margin of 69 percent to 28 percent; disapprove of Fay caning by margin of 47 percent to 46 percent.).

${ }_{104}$ See, for example, Bailey, Paddling Bill, LA Times at A1 (cited in note 101) (public punishment designed to magnify humiliation); Kimberly Crockett, Paddling: But Who Believes It Will Deter Crime?, Phoenix Gazette B7 (Feb 9, 1995) (available in LEXIS) (same). 
impoverish society. Accordingly, society should impose fines rather than imprisonment whenever feasible. ${ }^{105}$

This well rehearsed defense of fines has carried little weight in the political process. ${ }^{106}$ Indeed, the law has moved in exactly the opposite direction. Before 1984, white-collar offenders were much more likely to be fined and much less likely to be imprisoned than common offenders. ${ }^{107}$ Optimal deterrence theorists applauded this pattern. ${ }^{108}$ Far from ratifying it, however, Congress invited the United States Sentencing Commission to consider requiring judges to sentence white-collar offenders to prison terms; the Commission thereafter issued guidelines doing exactly that. ${ }^{109}$ Congress also substantially increased the maximum fines for white-collar offenses. ${ }^{110}$ But these penalties were authorized as supplements to and not as substitutes for the prison terms required by the Guidelines.

Is there an explanation for American jurisdictions' traditional reluctance to make greater use of fines? One is that fines are

${ }_{105}$ See Gary Becker, Crime and Punishment: An Economic Approach, 76 J Pol Econ 169, 193-98 (1968); Posner, 17 Am Crim L Rev at 409-11 (cited in note 3); Steven Shavell, Criminal Law and the Optimal Use of Nonmonetary Sanctions as a Deterrent, 85 Colum L Rev 1232, 1236-38 (1985); Morris and Tonry, Between Prison and Probation at 114-15 (cited in note 3 ).

106 See Morris and Tonry, Between Prison and Probation at 140-41 (cited in note 3) (noting traditional opposition).

107 See, for example, John L. Hagan and Ilene H. Nagel, White-Collar Crime, WhiteCollar Time: The Sentencing of White-Collar Offenders in the Southern District of New York, 20 Am Crim L Rev 259 (1982). See also United States Sentencing Commission, Supplemental Report at 18 (cited in note 4).

${ }^{108}$ See, for example, John R. Lott, Jr., Do We Punish High Income Criminals Too Heavily?, 30 Econ Inq 583, 604 n 39 (1992); Posner, 85 Colum L Rev at 1209-10 (cited in note 23); Joel Waldfogel, Are Fines and Prison Terms Used Efficiently? Evidence on Federal Fraud Offenders, 38 J L \& Econ 107 (1995).

${ }_{109}$ See 28 USC $\$ 994(\mathrm{~m})$ (1994) (directing Commission to increase severity of punishments for crimes in which existing sentencing practices do "not accurately reflect the seriousness of the offense"); Comprehensive Crime Control Act of 1984, S Rep No 98-225, 98th Cong, 2d Sess 177 (1984), reprinted in 1984 USCCAN 3182, 3360 (suggesting that Commission "might conclude that such a category of [white-collar] offenders should serve a term of imprisonment, or a longer term than currently served, for purposes of punishment and deterrence"); United States Sentencing Commission, Guidelines Manual § 1A4(d) (Nov 1990) ("Under pre-guidelines sentencing practice, courts sentenced to probation an inappropriately high percentage of offenders guilty of certain economic crimes, such as theft, tax evasion, antitrust offenses, insider trading, fraud, and embezzlement, that in the Commission's view are 'serious.'”); Stephen Breyer, The Federal Sentencing Guidelines and the Key Compromises upon which They Rest, 17 Hofstra L Rev 1, 20-22 (1988) (explaining Commission's decision to require imprisonment for all but the most trivial white-collar offenses).

110 See Criminal Fine Enforcement Act of 1984, Pub L No 98-596, 98 Stat 3134, 3137, codified at 18 USC $\S 3623$ (Supp 1985); Criminal Fine Improvements Act of 1987, Pub L No $100-185$, 101 Stat 1279,1280 , codified at 18 USC $\S 3571$ (1994). 
insufficiently retributive. Fines just don't make offenders suffer as much as prison terms.

But the proponents of fines have a ready and convincing answer to this claim: says who? It is essentially impossible to measure the subjective displeasure individuals suffer when punished. ${ }^{111}$ The only reliable way to gauge the disutility associated with a particular penalty is to see what effect the threat of it has on behavior. If potential offenders would be as deterred by a particular fine as they would by a particular term of imprisonment, it can be inferred that losing that amount of money hurts them just as much as that amount of incarceration. ${ }^{112}$ By thus fashioning a proper exchange rate between imprisonment and fines, and imposing the latter whenever feasible, society would get just as much retribution at a smaller cost.

At this point, the retributivist is likely to invoke equality. Fines are not feasible for everyone, first, because penalties large enough to deter serious offenses are likely to exceed the assets of poor offenders and, second, because imprisonment is needed to incapacitate, not just deter, violent offenders. Fine proponents acknowledge this, and argue that fines should be reserved mainly for white-collar offenses, since those are the ones most likely to be committed by wealthy individuals and least likely to involve violence. ${ }^{113}$ But to impose prison terms only on the poor, retributivists argue, illegitimately discriminates on the basis of wealth. ${ }^{114}$

Once again, the defenders of fines advance a compelling rebuttal-namely, that the retributivists' conception of equality is excessively formal. The retributivist argument assumes that the

11 See Morris and Tonry, Between Prison and Probation at 94-95 (cited in note 3).

112 See Posner, $17 \mathrm{Am}$ Crim L Rev at 411 (cited in note 3). Compare Morris and Tonry, Between Prison and Probation at 102-04 (cited in note 3) (arguing that the equivalence of punishments should be determined by their respective contributions to the purposes of punishment and not their capacity to induce subjective pain).

${ }^{113}$ See Posner, 17 Am Crim L Rev at 409-411, 413 (cited in note 3). The ideal regime, from an optimal deterrence standpoint, would imprison only offenders too poor to pay the optimum fine. See Shavell, 85 Colum L Rev at 1236-37 (cited in note 105). But that approach would be contrary to current equal protection doctrine. See Williams $v$ Illinois, 399 US 235, 244 (1970) ("[T] he Equal Protection Clause . . . requires that the statutory ceiling placed on imprisonment for any substantive offense be the same for all irrespective of their economic status."); Tate $v$ Short, 401 US 395 (1971) (finding that states cannot imprison indigent defendants who cannot pay their fines in full). No credible constitutional challenge could be made, however, to a regime that does almost the same thing by tailoring fines to the wealth of the average offender for different categories of crime.

114 See, for example, Andrew von Hirsch, Doing Justice: The Choice of Punishments 122 (Northeastern 1976). 
only way to treat affluent and nonaffluent offenders equally is to treat them exactly the same way. But it is also possible to treat them equally by imposing different sentences that make them suffer the same amount (as measured by the deterrent effect of those sentences). Fines can inflict greater disutility on rich offenders, whose capacity to pay those fines is great, than on poor ones, whose capacity to suffer financial loss is capped by their limited assets. ${ }^{115}$ Indeed, because they lose more income and endure greater reputational harm, affluent offenders likely suffer more when imprisoned than do nonaffluent ones. ${ }^{116}$ Thus, the retributivist's narrow "same treatment" conception of equality not only raises the cost of punishment but in fact discriminates against wealthy offenders by making them suffer disproportionately relative to poor ones.

These arguments are fairly persuasive, but only because the retributivist position that they attack ignores the expressive dimension of punishment. So, for that matter, does the optimal deterrence case for fines. Once the expressive significations of fines and imprisonment are brought into focus, the retributive objections become a more compelling explanation (if not a complete defense) of the status quo.

Fines, I will argue, are politically unacceptable not because the public perceives that they are insufficiently severe, but because it believes that fines are insufficiently expressive of condemnation. To be sure, it is unlikely that fines mean only one thing to all segments of American society, just as corporal punishment did not mean the same thing to all Americans in the nineteenth century, and probably does not today. But like corporal punishment, fines do have a meaning that is sufficiently concrete, sufficiently widespread, and sufficiently at odds with appropriate condemnation, to rule them out as a serious alternative to imprisonment. I'll first sketch out my basic position on the social meaning of fines and then discuss the evidence that supports my interpretation.

115 A countervailing factor is that the marginal disutility of a particular fine might be greater for a poor offender than for an affiuent one. See Shavell, 85 Colum L Rev at 1237 n 19 (cited in note 105). Sorting these effects out theoretically and empirically, however, is extremely complicated. See generally David D. Friedman, Reflections on Optimal Punishment, Or: Should the Rich Pay Higher Fines?, 3 Res L \& Econ 185 (1981).

${ }^{116}$ See Lott, $95 \mathrm{~J}$ Pol Econ at 1309-12 (cited in note 5); Posner, 17 Am Crim L Rev at 415 (cited in note 3). See also Stanton. Wheeler, Kenneth Mann, and Austin Sarat, Sitting in Judgment: The Sentencing of White-Collar Criminals 149 (Yale 1988) (documenting that federal judges prior to Guidelines accepted these claims). 
As I've emphasized, afflictions can be equivalent along many dimensions-including pain and deterrent effect-but still differ radically in meaning. Robert Cooter recognizes this when he distinguishes between a "sanction"-which he defines as "a detriment imposed for doing what is forbidden"-and a "price"-which he defines as a detriment that an actor is required to endure "in order to do what is permitted."117 Prison, on this account, is clearly a sanction; because liberty is so universally and intensely valued, taking it away is our society's most potent symbol of moral condemnation. Fines condemn much more ambivalently. When combined with a term of imprisonment, no one doubts that fines convey moral disapproval. But when fines are used as a substitute for imprisonment, the message is likely to be that the offenders' conduct is being priced rather than sanctioned. And while we might believe that charging a high price for a good makes the purchaser suffer, we do not condemn someone for buying what we are willing to sell.

Cooter examines the respective regulatory properties of sanctions and prices; I want to show how their respective meanings affect their political acceptability. Imprisonment, as a sanction, invariably condemns; fines, when viewed as prices, do not. Accordingly, when it lacks this signification, a fine, no matter how large, won't be viewed as an adequate substitute for an appropriate term of imprisonment.

This expressive account gives more substance to the retributive critique of fines. Punishment, on this account, does more than make an offender suffer; it condemns his acts as morally wrong. What makes fines, when viewed as mere prices, unacceptable is that they fail to impose the condemnation that the offender deserves-however much disutility they impose. The expressive dimension of punishment also grounds the sensibility that it violates equality to fine the rich while imprisoning the poor. The white-collar offender who is fined might suffer as much as the common offender who is imprisoned, but against the background of social norms he clearly is not being condemned as much. That kind of inequality does matter because appropriate condemnation is what punishment is all about.

117 Robert Cooter, Prices and Sanctions, 84 Colum L Rev 1523, 1524, 1525 (1984) (emphases in original). Compare H.L.A. Hart, The Concept of Law 39 (Clarendon 2d ed 1994) (distinguishing between monetary exactions understood as "taxes" and those understood as "punishments"). 
What is the evidence for this interpretation of the meaning of fines? It is amply supported, to begin, by casual observation. The imposition of a large fine rather than a prison sentence_- even for a relatively nonviolent offense, such as statutory rape or incest-often provokes the outraged retort that the offender is being permitted to "buy his way out" of the consequences of his actions; ${ }^{118}$ if the offense was committed in the course of commercial activities, a fine is likely to be derided as merely the "cost of doing business."119 Such a disposition, it is commonly asserted, trivializes the seriousness of the offense and denigrates the worth of the crime victim. ${ }^{120}$ When members of the public say this, they are interpreting fines as prices rather than as sanctions and objecting to them on that basis. ${ }^{121}$

The behavior of democratically elected lawmakers likewise suggests that fines are deemed an expressively inadequate substitute for imprisonment. The reason that Congress in 1984 questioned the prevailing judicial emphasis on fines for white-collar offenders was that this approach did "not accurately reflect the seriousness of [white-collar] offense[s]."122 This explanation pre-

118 See, for example, David Ranii, A Furor over an Alternative Sentence: Was Defendant Being Allowed to "Buy His Way Out" of Prison?, Natl L J 8 (Dec 5, 1983) (reporting uproar in aftermath of a judge's proposal that a man who sexually molested his stepchildren pay between one and two million dollars to a rape counseling center in exchange for a shortened prison sentence); Alan L. Otten, Mounting Charges of Leniency, Unfairness Hobble Advocates of Non-Jail Sentences, Wall St J Section 2 at 31 (Oct 30, 1985). See also Editorial, Instead of Jail: "Welcome Reptile!", NY Times A22 (Feb 17, 1988) ("The] impression [of large fine in lieu of imprisonment for wealthy tax evader] is that if you have enough money, you can buy your way out of prison, much as Civil War conscripts could buy a replacement. Money really counts, the sentence seems to say ....").

119 See, for example, Md. Wetlands Conviction Stirring Heated Debate, Wash Post F6 (Feb 20, 1993) (quoting prosecutor of environmental crimes: "[p]rison is entirely appropriate in these cases, if we just handed out fines it would be regarded simply as a cost of doing business"); Howard Murphy, Prescription for Resentment, Boston Globe 29, 30 (Nov 11, 1992) (quoting Medicaid fraud prosecutor: "[w]e wanted to send the message that if businessmen engaged in criminal acts, their activity would not be only a matter of paying a fine, like it's the cost of doing business, but rather some period of incarceration").

${ }^{120}$ See, for example, Debra J. Saunders, Beat the Wife, Pay a Fine, SF Chronicle A19 (June 20, 1994) (reporting growing sentiment that fining wife beaters while imprisoning assaulters demeans value of women and trivializes domestic violence); Michigan News Briefs, UPI Wire (Mar 6, 1989) (available in LEXIS) (victim "devastated" and community "outrage[d]" after judge fined rape offender rather than sentencing him to prison); Charles P. Alexander, Side Effects for a Pain Killer, Time 33 (Sept 2, 1985) (reporting consumer outrage over plea bargain that resulted in fine and no imprisonment for corporate officials responsible for concealing dangerous side effects of prescription drug).

${ }^{121}$ See, for example, Leslie Berestein, Landlord Convicted of Slum Charges, LA Times 9 (Oct 2, 1994) (available in LEXIS) (quoting prosecutor: fines for repeat housing code violations "[i]n effect . . . become[ ] a license to run slums").

${ }_{122} 28$ USC § 994(m) (emphasis added). 
supposes that different afflictions convey different attitudes about the nature of the offender's behavior, and that, at least sometimes, only imprisonment shows that society takes such offenses seriously.

Finally, the expressive inadequacy of fines is directly borne out by opinion surveys. Such studies consistently show that the public and (democratically accountable) decision makers view fines, by themselves, as insufficiently condemnatory for "serious" offenses. ${ }^{123}$ As the authors of one such study put it, "many people believe that the idea of an offender paying for his immorality is offensive, and that a fine is 'a pretty timid expression of moral indignation."'124

Criminologists Anthony Doob and Voula Marinos provide compelling empirical confirmation of this sensibility. ${ }^{125}$ Doob and Marinos presented test subjects with a list of crimes and asked them to identify which ones could appropriately be punished by fines alone. ${ }^{126}$ For a great number of offenses, the majority of respondents indicated that no fine, of any amount, would be an appropriate substitute for a prison sentence. ${ }^{127}$ It might be fair to assume that the respondents demanded prison for violent offenses in order to incapacitate; but other offenses for which they also viewed fines to be inappropriate-including, for example, nonconsensual sexual touching and cocaine distribution-were relatively nonviolent. ${ }^{128}$ In addition, when told to assume that stipulated prison sentences were appropriate for the same offenses, the respondents were able to specify appropriate alternative fines for some crimes but not for others. ${ }^{129}$

${ }^{123}$ See, for example, John Doble, Crime and Punishment: The Public's View 39-40 (Public Agenda Foundation 1987); John Doble and Josh Klein, Punishing Criminals: The Public's View 4-5 (Public Agenda Foundation 1989).

124 Hillsman, Sichel, and Mahoney, Fines in Sentencing at 162 (cited in note 2), quoting project advisor.

125 Anthony N. Doob and Voula Marinos, Reconceptualizing Punishment: Understanding the Limitations on the Use of Intermediate Punishments, $2 \mathrm{U}$ Chi L Sch Roundtable 413 (1995).

${ }_{126}$ Doob and Marinos describe their test subjects as "a heterogeneous sample of people in Toronto." Id at 430. I assume that Canadians and Americans are sufficiently similar in their views to make their findings relevant to an assessment of the American public's perceptions of fines.

127 Id at 431-32.

128 Id at 432 . This result is consistent with the oft-reported finding that the public views the seriousness of many types of white-collar offenses as equal to or greater than many violent common offenses. See John Braithwaite, Challenging Just Deserts: Punishing White-Collar Criminals, $73 \mathrm{~J}$ Crim L \& Criminol 723, 731-38 (1982) (describing numerous studies).

${ }^{129}$ See Doob and Marinos, 2 U Chi L Sch Roundtable at 432-33 (cited in note 125). 
These and like findings suggest that a politically acceptable exchange rate for fines and imprisonment cannot be constructed for at least some serious offenses. Such a translation may be possible for certain, relatively trivial offenses, but for those that exceed a certain threshold of seriousness no fine of any amount will adequately satisfy the demand for appropriate condemnation.

The meaning of fines in American society is no doubt the product of particular social and historical circumstances. In the abstract, fines could be viewed as sanctioning rather than merely pricing misconduct, just as, in the abstract, imprisonment could be viewed as merely pricing rather than sanctioning. ${ }^{130}$ Indeed, fines apparently are regarded as genuine sanctions in Western European nations, which use criminal fines much more extensively than do American jurisdictions. ${ }^{131}$

But however contingent, the social meaning of fines does necessarily constrain political reform. ${ }^{132}$ So long as fines express moral neutrality or ambivalence for a majority of Americans, they will remain a politically unacceptable substitute for imprisonment-whatever they could express or do express elsewhere. Just as Humpty Dumpty couldn't make the words of a real language mean exactly what he chose them to mean - "neither more nor less"133 - so those who construct a punishment language can't make particular forms of suffering express condemnation if, within a particular community, they just don't. ${ }^{134}$

${ }^{130}$ See Becker, $76 \mathrm{~J}$ Pol Econ at 195 (cited in note 105).

${ }^{231}$ See Morris and Tonry, Between Prison and Probation at 116-19 (cited in note 3).

${ }_{132}$ See generally J.M. Balkin, Cultural Software: A Theory of Ideology ch 2 (on file with U Chi L Rev).

${ }_{133}$ Lewis Carroll, Through the Looking-Glass, in Martin Gardner, ed, More Annotated Alice: Alice's Adventures in Wonderland and Through the Looking-Glass and What Alice Found There 253 (Random House 1990).

${ }^{134}$ The expressive inadequacy of criminal fines is no doubt in part an artifact of the law itself. The availability of alternative sanctions helps to construct the meaning of monetary penalties. In tort law, for example, punitive damages unambiguously express condemnation relative to the alternative of compensatory damages. See generally Marc Galanter and David Luban, Poetic Justice: Punitive Damages and Legal Pluralism, $42 \mathrm{Am}$ U L Rev 1393 (1993) (providing an expressive defense of punitive damages). But in criminal law, fines frequently express moral ambivalence or neutrality because the alternative of imprisonment condemns so unequivocally. This framing effect suggests the possibility that civil punitive damages might be politically acceptable as an alternative to imprisonment even when criminal fines are not. The question is whether the public would view the substitution of punitive civil regulation for criminal regulation as itself condoning rather than condemning the underlying conduct. Of course, even if the public would accept punitive civil damages as an alternative to imprisonment, there are numerous practical constraints on the feasibility of private civil actions as substitutes for criminal proceedings. See, for example, William M. Landes and Richard A. Posner, The Private Enforcement of Law, $4 \mathrm{~J}$ Legal Stud 1, 25 (1975). There may also be compelling moral 


\section{Community Service vs. Imprisonment}

Community service is another alternative sanction whose popularity in theory is matched by its unpopularity in practice. Community service orders have become increasingly common in recent years, but almost entirely as supplemental sanctions for offenses traditionally punished with probation and not as substitute sanctions for offenses traditionally punished with imprisonment. ${ }^{135}$ Again, I will argue that the political unacceptability of community service as an alternative to imprisonment stems from its social meaning.

Assessed under conventional theories of punishment, the public's antipathy toward community service is mysterious. From an optimal deterrence standpoint, the case for community service is the same as the case for fines: community service is just as effective as imprisonment for many offenses, and lots cheaper. ${ }^{136}$ From a retributivist standpoint, the objections are also likely to be the same, and are just as unconvincing. It is sometimes said that community service doesn't "really" hurt. But says who? This contention overlooks not only the value that offenders attach to their time and labor, but also the stigma associated with conviction, particularly for the middle-class and affluent offenders for whom community service would typically be a feasi-

reasons not to make such a substitution. See Paul H. Robinson, The Criminal/Civil Distinction and the Utility of Desert, 76 BU L Rev 201 (1996).

${ }^{135}$ See Zimring and Hawkins, Scale of Imprisonment at 183 (cited in note 2); Eugene Doleschal, The Dangers of Criminal Justice Reform, 14 Crim J Abstracts 133, 133-41 (1982); Alan T. Harland, Court-Ordered Community Service in Criminal Law: The Continuing Tyranny of Benevolence?, 29 Buffalo $L$ Rev 425, 443-46 (1980). This result is despairingly referred to by proponents of alternative sanctions as "net widening": when alternative sanctions are used not as substitutes for imprisonment but as supplements to probation, punishments become only more severe and more expensive. See Tonry, $2 \mathrm{U}$ Chi L Sch Roundtable at 397, 405-06 (cited in note 5). With the use of rigorous selection criteria, the Vera Institute pushed the representation of prison-bound offenders in its well known New York City program to nearly 50 percent, but even this ratio-the best by far in any reported study-failed to make community service a cost-effective replacement for imprisonment. See Douglas C. McDonald, Punishing Labor: Unpaid Community Service as a Criminal Sentence, in James M. Byrne, Arthur J. Lurigio, and Joan Petersilia, eds, Smart Sentencing: The Emergence of Intermediate Sanctions 182, 190 (Sage 1992).

136 See, for example, Douglas Corry McDonald, Punishment Without Walls: Community Service Sentences in New York 27-28 (Rutgers 1986) (New York City experiment indicates that closely supervised program of community service for lesser property offenders represents a cost-effective alternative to incarceration.); Malcolm M. Feeley, Richard Berk, and Alec Campbell, Between Two Extremes: An Examination of the Efficiency and Effectiveness of Community Service Orders and Their Implications for the U.S. Sentencing Guidelines, $66 \mathrm{~S}$ Cal L Rev 155, 191 (1992) (finding that community service is as effective as imprisonment when effectiveness is measured by recidivism rates). 
ble sanction. ${ }^{137}$ It is also sometimes said that community service creates inequality in sentencing since it treats affluent white-collar and petty common offenders more leniently than nonaffluent common offenders who get sentenced to prison. ${ }^{138}$ But again, this argument myopically focuses on the form of punishment and ignores the substantive disutility of it. If we look at the objective deterrent effect of such penalties, it should be perfectly possible, community service advocates contend, to construct an exchange rate that translates particular terms of imprisonment into equally unpleasant terms of community service. ${ }^{139}$ So community service looks, in theory, like a perfect way to satisfy retributivist concerns while increasing penal efficiency.

So why does the public balk? The answer, again, is that community service is expressively inadequate. Like corporal punishment, it both fails to say something true-that offenders deserve condemnation - and seems to say something false-that community service is a fitting way to mark the disgrace of criminals.

Cases in which community service is proposed as a substitute for imprisonment present a jarring spectacle. In one case, a once respected rabbi and businessman convicted of defrauding the residents of his nursing homes suggests that he be sentenced to administer a "Committee on Holocaust Studies"; ${ }^{140}$ in another, a dentist convicted of fondling sedated female patients is sentenced to provide free service to persons shunned by other dentists because they are infected with AIDS. ${ }^{141}$ We don't ordinarily condemn individuals who perform services such as these; we admire them.

This dissonance, not the perceived painlessness of such sanctions, is at the heart of the complaint that community service is a mere "slap on the wrist." Because requiring offenders to work in

${ }^{137}$ Compare Wheeler, Mann, and Sarat, Sitting in Judgment at 144-49 (cited in note 116) (documenting that federal judges before Guidelines viewed differential reputational and income-impairing effects of conviction as justifying less severe sentences for whitecollar offenders than for common offenders).

${ }^{138}$ See, for example, David A. Kaplan and Clara Bingham, A New Era of Punishment, Newsweek 50 (May 14, 1990) (" $[I]$ s doing a few chores at the local homeless shelter real punishment, or is it just preferential treatment for the Dior collared?") (emphasis in original); Andrea Sachs, Doing the Crime, Not the Time, Time 81 (Sept 11, 1989) (suggesting that community service sentences inject class bias into sentencing).

139 See Morris and Tonry, Between Prison and Probation at 173 (cited in note 3) (proposing imprisonment/community-service exchange rates).

${ }_{140}$ United States $v$ Bergman, 416 F Supp 496, 500-01 (S D NY 1976).

${ }^{141}$ See Sachs, Doing the Crime, Time at 81 (cited in note 138). 
"community-owned nursing homes, city parks, churches, local YMCA branches, [ ] organization[s] restoring run-down and abandoned buildings for low-income housing, senior citizens' centers, day care centers, Salvation Army centers"142 and the like just doesn't express condemnation, "[i]t is difficult to conceive of the[se] as 'punishments' at all."143 If society really took the offense seriously, it would select an affliction, like imprisonment, that unambiguously says as much. Against the background of social norms, community service, like fines, trivializes the magnitude of the offense and devalues the worth of the victim. ${ }^{144}$

What's more, the dissonance associated with such penalties does violence to public sensibilities about the positive meaning of community service. The premise of the criminal conviction is that the offender has committed a heinous act worthy of moral condemnation. Correspondingly, these sentences seem to say that community service-whether lecturing teens on the dangers of drug use or installing smoke alarms in an old-age home-is a form of affliction sufficiently disgraceful to mark the offender's conduct for what it is. But for a great many observers, this statement is manifestly false. Such a sentence thus devalues community service, denigrates the virtue of those who perform it, and shows contempt for the interests of those whom it is supposed to benefit.

This is a dominant and recurring sentiment in public criticism of community service. These statements are representative:

${ }^{142}$ McDonald, Punishment Without Walls at 34 (1986) (cited in note 136) (describing Vera Institute community service sentencing program in New York City).

${ }^{143}$ Bergman, 416 F Supp at 501 (rejecting proposed Holocaust Study Committee sentence).

${ }^{14}$ See, for example, Reuters, Court Upholds Korean Grocer's Probation in Killing (Apr 21, 1992) (AM Cycle) (available in LEXIS) (reporting outrage of African-American community at community service sentence of Korean grocer who shot and killed African-American shoplifter); Editorial, Deaver's Community Service? Perform it in Jail, Newsday 72 (Sept 28, 1988) (Community service trivializes seriousness of political corruption offenses.); Jack W. Germond and Jules Witcover, Sentencing of North Takes the Easy Way Out, St Petersburg Times 20A (July 7, 1989) (available in LEXIS) (Oliver North's community service sentence "provides ammunition to those who contend North didn't do much, or even anything, wrong."); Kaplan and Bingham, New Era, Newsweek at 50 (cited in note 138) (quoting president of Mothers Against Drunk Driving: "By only giving [drunk driver convicted of manslaughter] community service, the judge did not send the right message that this is a violent crime similar to rape and murder."); Christopher Kilbourne, Mercy without Justice in a Ringwood Rape Case, Record B6 (Dec 16, 1994) (Bergen County, NJ) (available in LEXIS) (arguing that community service rather than imprisonment for rape trivializes seriousness of offense); Arlo Wagner, Picketers Protest Light Rape Sentence, Wash Times B4 (Oct 25, 1989) (available in LEXIS) (reporting public protests after sentence of one day in jail plus one thousand hours of community service for rape). 
Many of us noncriminals perform community service not to avoid jail but because we want to. Perhaps the bench thinks the inconvenience of not being able to go after big bucks for a while is fitting punishment for corporate wrongdoers. I consider community service an honor that should not be tainted by judicial wrist slapping. ${ }^{145}$

Is this community service construed as some sort of penance, like having to recite a string of Hail Marys? If so, what does that make the everyday jobs of drug counselors, educators and law enforcement officers in the antidrug effort? Or does such community service constitute punishment only when imposed on a bureaucrat fallen from the empyreal heights? ${ }^{146}$

It is important that people with short memories recall that not so long ago-but before Watergate, Iran-contra, junk bonds-community service was inspired only by public-spiritedness and generosity. Believe it or not, there are people who, without charisma or notoriety, work among the needy, not because they are sentenced to do so by a judge but rather because they are moved by the dictates of their own hearts. ${ }^{147}$

As a teacher, I find it insulting to my profession that this person, after pleading guilty to a felony, is going to perform in the capacity of an educator as punishment for his offense. ${ }^{148}$

Doesn't the public have a choice? Suppose parents are less than thrilled with the idea of [Oliver] North doing his community service bit as part of their children's civics lesson. ... And the downtrodden, homeless and needy-how do they feel about swarms of felons swooping down on them[?] What about their choices? ${ }^{149}$

145 Robert A. Weisberg, Letter to the Editor, US News \& World Rep 4 (July 22, 1985) (emphasis in original).

${ }_{146}$ Steven F. Sage, Letter to the Editor, Wash Post A22 (July 13, 1989).

147 Barbara Gordon, Community Service, Mark of Disgrace, NY Times A17 (Mar 12, 1990).

148 Robert Mathews, Letter to the Editor, SF Examiner A20 (Mar 30, 1995).

149 Gordon, Community Service, NY Times at A17 (cited in note 147). 
The only risk is that [community service] will give honest labor a bad name: cleaning ladies shouldn't be tainted by their association with celebrities. Zsa Zsa Gabor should only be so lucky. ${ }^{150}$

Community service, in short, is an expressively irrational means of punishment not just because it doesn't condemn, but because it threatens the integrity of expressive conventions that the public deeply values. We choose our actions against a background of social norms that invest them with the meaning appropriate to our goals and purposes. The significations associated with community service are valued because they enable us to occupy a particular role-that of good citizen-that entitles us to respect ourselves and to be respected by others. The law clearly has the power to alter the meanings of particular actions; ${ }^{151}$ and when it does, there isn't always a ready replacement for the actions whose meanings have been so effaced. ${ }^{152}$ In a liberal, individualistic society, the vocabulary for meaningfully expressing one's public-spiritedness is perceived to be thin and fragile. The public objects to using community service as punishment, then, because it understandably views this type of sanction as depleting the stock of expressive conventions on which a valued role depends.

Again, in a different cultural setting, community service could bear a different and less problematic signification. ${ }^{153}$ No doubt it does for those who support it: by forcing a wrongdoer to engage in socially valued activities, they might contend, society shows him how a virtuous person ought to behave. But that is

150 Kaplan and Bingham, New Era, Newsweek at 51 (cited in note 138).

151 See generally Lessig, 62 U Chi L Rev 943 (cited in note 20).

is2 See William M. Landes and Richard A. Posner, Salvors, Finders, Good Samaritans, and Other Rescuers: An Economic Study of Law and Altruism, $7 \mathrm{~J}$ Legal Stud 83, 98-100, 121-22 (1978) (suggesting that the imposition of a legal duty to assist strangers in distress would eviscerate altruistic meaning of such assistance).

${ }^{153}$ Likewise, the signification of community service is influenced by the legal context in which it is used. As mentioned, community service has become increasingly popular for offenses traditionally punished only by probation. See text accompanying note 135 . The political acceptability of community service in that setting again reflects a framing effect: where the perceived alternative-in this case, probation-is understood to be relatively noncondemnatory, a sanction such as community service is more likely to be perceived as expressing condemnation than when the perceived alternative is imprisonment. See note 134 (discussing framing effect in connection with fines). The same framing effect explains the career of "boot camps," "intensive probation supervision," and "house arrest," all of which were intended to be substitutes for imprisonment, but which have become primarily supplements to straight probation. See notes 61-62 and accompanying text. 
not how the great majority of Americans now perceive community service, and for that reason, there is little to be gained by advancing such an interpretation. To be useful, theorists must do more than tell stories about politically unacceptable alternative sanctions; they must identify politically acceptable ones that have the potential to enhance society's well-being.

\section{ENRICHING OUR PUNITIVE VOCABULARY: THE REDISCOVERY OF SHAME}

So far I have concentrated on showing how the social meaning of alternative sanctions, in the form in which they are conventionally proposed, makes them politically unacceptable. I will now examine how the expressive dimension of punishment can be used to identify politically acceptable reforms.

To begin, nothing I've said shows that there is not a problem worth solving with alternative sanctions. The expressive dimension of punishment helps to describe how deep-seated sensibilities inform a society's institutional choices. But nothing in that phenomenon commits us to accept uncritically either the sensibilities or the institutions that happen to satisfy them. All else equal, a society is certainly better off if it can substitute a cheaper pairing of sensibilities and institutions for a costly pairing. ${ }^{154}$

Thus, American jurisdictions would be better off if they could either reform the expressive sensibilities that make cheaper alternatives to imprisonment unacceptable or identify additional cheaper alternatives that satisfy those sensibilities.

Of these two options, the first is a nonstarter. Wholly apart from whether it is appropriate for a liberal society to concern itself with the quality of its citizens' values, a project to reform expressive sensibilities through self-conscious engineering would be extraordinarily complicated. Our knowledge of how to create and alter social norms is relatively primitive. ${ }^{155}$ It's unclear how a legislature would even start to transform the understandings that make corporal punishment express inequality, fines moral indifference, and community service public-spiritedness.

The second option-identifying alternative sanctions that satisfy extant expressive sensibilities-has considerably more promise. Expressive modes of valuation resist quantitative met-

${ }^{354}$ See Lessig, 62 U Chi L Rev at 1002-04 (cited in note 20).

155 But see id at 1012-14 (discussing "inhibition" and "ritual" as state-sponsored techniques for changing social meaning). 
rics, but ordinarily accommodate a wide range of actions that embody appropriate meanings in different contexts. ${ }^{156} \mathrm{~A}$ person who sets out to produce the same amount of "pleasure" in his children, or who insists on mechanically treating all of them "the same," is unlikely to be a good parent; if he is properly attuned to social meaning, however, the incommensurability of his children's well-being will not prevent him from identifying actions that appropriately express his love for each. Likewise, from an expressive point of view, what is critical is not that society inflict the same amount of pain on all wrongdoers or impose the same form of deprivation on all, but that it select afflictions that unambiguously express condemnation against the background of social norms. It would be strange if imprisoning all serious offenders were the only way to do that.

My goal in this Part is to show that it isn't. Social norms permit the construction of a rich array of shaming practices, all of which unambiguously convey moral condemnation. By using these practices, either alone or in combination with conventional sanctions such as fines and community service, American jurisdictions can fashion politically acceptable alternative sanctions.

\section{A. The Shaming Alternative}

Early Americans turned to imprisonment in large part because they believed that existing criminal penalties had lost the power to shame. ${ }^{157}$ It is perfectly fitting, then, that contemporary Americans are rediscovering shaming penalties as they attempt to extricate themselves from their excessive reliance on imprisonment. In this Part, I offer an overview of what those penalties are and why they are more likely to be embraced by the public than conventional alternative sanctions.

\section{What shaming penalties are.}

The last decade has witnessed the advent of a wide variety of shaming sanctions. Although categorizing them risks understating their diversity and richness, these penalties can be grouped into four classes: stigmatizing publicity, literal stigmatization, self-debasement, and contrition.

Stigmatizing publicity is the most straightforward. Penalties in this class attempt to magnify the humiliation inherent in con- 
viction by communicating the offender's status to a wider audience. Some municipalities, for example, publish offenders' names in newspapers or even on billboards, a disposition that is especially common for men convicted of soliciting prostitutes. ${ }^{158}$ Other jurisdictions broadcast the names of various types of offenders on community-access television channels. ${ }^{159}$

Literal stigmatization is just that-the stamping of an offender with a mark or symbol that invites ridicule. Some judges order petty thieves to wear t-shirts announcing their crimes. ${ }^{160}$ Others achieve the same effect with brightly colored bracelets that read "DUI Convict," "I Write Bad Checks," and the like. ${ }^{161}$ One judge ordered a woman to wear a sign declaring "I am a convicted child molester."162

Less dramatic but even more common are penalties that attach stigmatizing marks to property. Some jurisdictions now require persons guilty of drunk driving to display special license plates or bumper stickers. ${ }^{163}$ Courts have also ordered those

159 For the use of stigmatizing publicity for solicitors, see Jonathan Alter and Pat Wingert, The Return of Shame, Newsweek 21, 24 (Feb 6, 1995) (La Mesa, Cal); Mark Journey, St. Petersburg to Name "Johns" on TV, St. Petersburg Times 2 (July 10, 1993) (available in LEXIS) (St. Petersburg, Fla); David Talbot, Johns Face Shame with TV Fame, Boston Herald 6 (Feb 19, 1995) (Miami, Fla and Canton, Ohio). For other offenses, see Lindsay v State, 606 S2d 652 (Fla Dist Ct App 1992) (drunk driving); Joseph R. Tybor, Unusually Creative Judges Now Believe Some Punishments Can Fit the Times, Chi Trib Section 3 at 1, 6 (July 3, 1988) (same, Mlinois); Molly Sinclair, Montgomery Plans to Issue List of Convicted Drug Offenders, Wash Post B1 (Jan 21, 1987) (drug offenses in Montgomery County, Maryland); Clifford J. Levy, Cracking Down in a Drinking Town, NY Times Section 1 at 21 (July 9, 1994) (public urination); Criminal Wrongs and Juvenile Rights, NJ Lawyer 6 (Aug 1, 1994) (available in LEXIS) (juvenile offenders). See also Paul Hemp, A Deadbeat Dad's Story, Boston Globe Magazine 22 (Mar 26, 1995) (posters with names and pictures of men who are delinquent in child support).

159 See Danny Westneat, Humiliation is Latest Weapon in Crime Fight-But Some Cities Have Found People Have No Shame, Seattle Times A1 (Jan 27, 1995) (reporting that Kent, Washington, broadcasts names of solicitors and drunk drivers); Cities Try to Shame Prostitutes and Johns Out of Town, Morning Edition, Natl Pub Radio (Feb 17, 1995) (Trans \#1545-3) (available in LEXIS) (reporting that Spokane, Washington, broadcasts names of solicitors and drug offenders). See also Talbot, Johns Face Shame, Boston Herald 6 (cited in note 158) (broadcast of arraignments of men convicted of soliciting prostitutes).

${ }_{160}$ See, for example, Lisa Fujimoto, Judge Orders Public Humiliation, Gannett News Serv (Jan 3, 1990) (available in LEXIS) (California man convicted of larceny ordered to wear shirt stating: "I am on felony probation for theft. My record plus two six-packs equal four years."); AP, Creative Sentence Given to Shoplifter, SD Union-Trib A3 (July 2, 1992) (Visalia, Cal) ("I am a thief" shirt).

${ }^{161}$ See Beverly Shepard, A Public Slap on the Wrist, Atlanta J \& Const C1 (Oct 19, 1991).

${ }_{162}$ See Reuters, Sex Offender Ordered to Wear Her Guilt, Chi Trib Section 1 at 3 (May 17, 1988) (Seattle, Wash).

${ }_{163}$ See, for example, Iowa Code Ann $\S 321 J .4 A(4)(a)$ (West Supp 1995); Goldschmitt $v$ 
convicted of sexual assaults and other crimes to post signs at their residences warning others to steer clear. ${ }^{164}$

Self-debasement penalties involve ceremonies or rituals that publicly disgrace the offender. In a contemporary version of the stocks, for example, some communities require offenders simply to stand in public spaces, such as the local courthouse, with signs describing their offenses. ${ }^{165}$ More imaginative forms of self-debasement attempt to match the penalty to the character of the offense. A judge in Tennessee orders convicted burglars to permit their victims to enter their homes and remove items of their choosing. ${ }^{166}$ In New York, a slumlord was sentenced to house arrest in one of his rat-infested tenements (where tenants greeted him with the banner, "Welcome, You Reptile!"). ${ }^{167}$ Hoboken, New Jersey, requires Wall Street brokers and others who urinate in public to clean the city's streets. ${ }^{168}$ This is only a small sam-

State, 490 S2d 123 (Fla Dist Ct App 1986) (upholding requirement that offender display bumper sticker reading "CONVICTED D.U.I."); Follow-up, Tagging Drunks, NY Times Section 1 at 49 (Nov 20, 1983) (Texas bumper sticker: "The owner of this vehicle is on probation in the County Court of Law of Fort Bend County, Texas, for driving while intoxicated. Report unsafe driving to Adult Probation Department."); Suzanne Fields, Going After the Parents, Wash Times F1, F4 (Aug 15, 1989) (bumper sticker for parents of children who violate town curfew: "My children are not my responsibility. They are yours."). See also Ohio Rev Code Ann $\S \S 4503.231,4507.02$ (F)(2) (Baldwin 1995) (authorizing distinctive license plates for specified driving-related offenses). The New York Court of Appeals recently invalidated such a sentence for a drunk-driving offender on the ground that state law did not authorize this disposition. See People v Letterlough, 86 NY2d 259, 631 NYS2d 105, 108-10 (1995). However, the trial judge responsible for these sentences has continued to impose them in cases in which offenders consent, thereby insulating their punishments from appellate review. See Maureen Fan, Driver Asks for DWI Tag Penalty, Newsday A4 (June 29, 1995).

${ }^{16 t}$ See State v Bateman, 95 Or App 456, 771 P2d 314 (1989) (upholding requirement that man post sign on property and vehicle stating: "Dangerous Sex Offender"); Sam Diaz, Judge Broadman Facing Hearing in Fresno Today, Fresno Bee B3 (July 17, 1995) (sign outside home of California child molester: "Do not enter, I am under house arrest."); Judge Orders Child Molester Not to Play Piano for 20 Years, Charleston Gazette 9A (May 20, 1994) (available in LEXIS) (Texas judge orders sign for child molester.); Stuart $M$. Wise, Judge Turns Confessing to a Crime Into a Religious Experience, Natl L J 47 (Feb 6, 1984) (sign ordered by federal district court in Tennessee: "[Offender] bought a stolen car. He is a thief.").

${ }_{165}$ See Fields, Going After the Parents, Wash Times at F1, F4 (cited in note 163) (Arkansas municipality requires parents of children who violate curfew to be put on public display.); Across the USA: News From Every State, USA Today 8A (Apr 22, 1993) (man in South Carolina ordered to sit outside courthouse for 10 days with sign, "I am a Drunk Driver").

${ }_{166}$ See Mark Curriden, Making Punishments Fit the Crime Often Not Popular, Atlanta Const A3 (Jan 9, 1992).

${ }^{167}$ See Don Terry, Landlord in His Own Jail: Tenants Debate His Fate, NY Times B1, B5 (Feb 18, 1988). See also Tybor, Unusually Creative Judges, Chi Trib Section 3 at 1 (cited in note 158) (same sentence for California slumlord).

${ }^{168}$ See Phil Reeves, Tales of the City, Independent 22 (Nov 15, 1994) (Manchester, 
ple; self-debasement sanctions are as diverse and particular as the crimes that they are used to punish. ${ }^{169}$

Contrition penalties come in two forms. The first requires offenders to publicize their own convictions, describing their crimes in first-person terms and apologizing for them. ${ }^{170}$ These penalties combine stigmatizing publicity with an element of selfdebasement; the sincerity of the offenders' remorse seems largely irrelevant.

Another form of contrition is the apology ritual. In Maryland, for example, juvenile offenders must apologize on their hands and knees and are released from confinement only if they persuade their victims that their remorse is sincere. ${ }^{171}$ Other jurisdictions use community-based sanctions that include public apologies and appropriate reparations. ${ }^{172}$ Because many of these penalties contemplate genuine rapprochement, apology rituals seem to be used primarily in cases in which the offender is connected to the victim by family or close community ties.

England) (available in LEXIS).

169 See, for example, People v McDowell, 59 Cal App 3d 807, 130 Cal Rptr 839 (1976) (purse snatcher ordered to wear tap shoes); Editorial, Punishment: Judges Need More Creative Ways to Handle Non-Violent Criminals, Cin Enq A10 (June 2, 1994) (man convicted of harassing former wife ordered to "let the ex-wife spit in his face"); Ruth Rendon, A Lesson in Discipline: Kids' Truancy Lands Moms Back in School, Houston Chronicle 21A (Apr 9, 1993) (parent of chronically truant student ordered to attend school with child); Ken Armstrong, Parents Sent Back to School to Watch over Truant Kids, Chi Trib Section 1 at 1 (Nov 6, 1994) (same); Judge Orders Molester Not to Play Piano, Charleston Gazette at 9A (cited in note 164) (piano teacher convicted of molesting students ordered to give away piano and refrain from playing for twenty years).

170 See Kerry Elizabeth Knobelsdorff, Choosing Between Public Humiliation and Jail, Christian Sci Monitor 3 (Jan 2, 1987) (describing widespread use of such penalties in Oregon, Oklahoma, and Washington); Periscope, Flogging?, Newsweek 6 (Apr 22, 1991) (New Hampshire man ordered to publicize conviction for sexually assaulting minor); Richard Phillips, Shame as a Deterrent, Chi Trib Section 1 at 20 (July 27, 1988) (company ordered to publish apologies for dumping carcinogenic chemicals); Clarence Peterson, The Power of Public Humiliation, Chi Trib Section 5 at 1 (Dec 2, 1986) (Oregon thief ordered to publicize conviction); Suzanne Steel, National Ads Expose Steer Tamperings, Columbus Dispatch 2S (Feb 19, 1995) (fraud); Carol J. Castaneda, False Rape Charge Apologized for in Ads, Gannett News Serv (Sept 5, 1990) (available in LEXIS).

171 See Alter and Wingert, Return of Shame, Newsweek at 21 (cited in note 158).

172 Id at 22 (use of such sentences by Tennessee judge); Wise, Judge Turns Confessing Into Religious Experience, Natl L J at 47 (cited in note 164) (car thief ordered to apologize to church congregation); Robert Franklin, Making Amends: City Explores Punishment for Liquor Store Theft, Minn Star-Trib 1B (Dec 12, 1994) (describing such a penalty for offender convicted of embezzlement). 


\section{What shaming penalties mean.}

The proponents of alternative sanctions shouldn't be entirely surprised by the growing popularity of shaming penalties. Much of their appeal is simply that they are cheaper than imprisonment. Not all offenders who receive shaming penalties would otherwise have been incarcerated, but many of them would have. Courts use shaming penalties to punish a wide array of offenses, including drunk driving, ${ }^{173}$ larceny, ${ }^{174}$ embezzlement, ${ }^{175}$ assault (sexual and nonsexual), ${ }^{176}$ burglary, ${ }^{177}$ perjury, ${ }^{178}$ toxicwaste dumping, ${ }^{179}$ and drug distribution. ${ }^{180}$ When imposed for crimes such as these, shaming penalties free up imprisonment resources for offenders who more urgently demand incapacitation. ${ }^{181}$

But shaming penalties are also emerging as a serious rival of imprisonment because they do something that conventional alternative sanctions don't do: express appropriate moral condemnation. Such penalties, one court explained, "inflict[ ] disgrace and contumely in a dramatic and spectacular manner." 182 This dimension of meaning sets shaming penalties apart from fines and community service, which seem unsatisfactory precisely because they condemn the offender's acts only equ' ,ocally. ${ }^{183}$

${ }^{173}$ See notes 158-59, 161, 163 and accompanying text.

${ }^{174}$ See, for example, Peterson, Power of Public Humiliation, Chi Trib Section 5 at 1 (cited in note 170); Wise, Judge Turns Confessing Into Religious Experience, Natl L J at 47 (cited in note 164).

175 See, for example, Franklin, Making Amends, Minn Star-Trib at 1B (cited in note 172).

176 Editorial, Punishment, Cin Enq at A10 (cited in note 169). See also notes 162, 164, 169-70.

177 See, for example, Curriden, Making Punishments Fit, Atlanta Const at A3 (cited in note 166); Thomas B. Rosenstiel, Some Crooks Get A Choice: Go to Jail-or Apologize, LA Times 1 (Sept 17, 1986).

${ }^{178}$ See, for example, United States v Clark, 918 F2d 843, 845 (9th Cir 1990); Castaneda, False Rape Charge, Gannett News Serv (cited in note 170).

${ }_{179}$ See, for example, Phillips, Shame as Deterrent, Chi Trib Section 1 at 20 (cited in note 170); Martha Middleton, Sentencing: The Alternatives, Natl L J 1 (Apr 23, 1984).

280 See, for example, Sinclair, Montgomery Plans to Issue List, Wash Post at B1 (cited in note 158).

181 See, for example, Richard Lacayo, Considering the Alternatives, Time 60 (Feb 2, 1987) (identifying cost-effectiveness as rationale for resort to shaming penalties); Jay Matthews, Freedom Means Having to Say You're Sorry, Wash Post A3 (Nov 9, 1986) (same).

${ }_{152}$ Goldschmitt $v$ State, 490 S2d 123, 125 (Fla Dist Ct App 1986), citing United States $v$ William Anderson Co., 698 F2d 911, 913 (8th Cir 1983).

${ }_{183}$ See, for example, Maureen Fan, Red-Faced Offender: Is It a Real Shame?, Newsday A27 (June 21, 1995) (quoting head of the Correctional Association of New York: "[o]ne of the reasons why people find these kinds of things appealing is not only because they think 
In fact, the expression of condemnation is at least as central to shaming penalties as the infliction of shame itself. Shame is the emotion that a person experiences when she believes that she has been disgraced in the eyes of persons whom she respects. ${ }^{184}$ Most offenders punished by shaming penalties are likely to feel shame. But some probably do not, just as some offenders do not view imprisonment as vitiating the respect of their peers. ${ }^{185}$ The public's realization that not all offenders view such punishments as disgraceful, however, does not diminish the resonance of either shaming penalties or imprisonment as symbols of the community's moral disapproval. If anything, the perception that the offender is not shamed by what is commonly understood to be shameful would reinforce onlookers' conclusion that he is depraved and worthy of condemnation. ${ }^{186}$

Shaming penalties might even more accurately be described as degradation penalties. All of them satisfy what Harold Garfinkel identifies as the "conditions of successful status degradation ceremonies": they are imposed by an agent invested with the moral authority of the community; they denounce the wrongdoer and his conduct as contrary to shared moral norms; and they ritualistically separate the wrongdoer from those who subscribe to such norms. ${ }^{187}$ It is not a condition of a successful degradation ceremony that it induce any particular belief or emotion on the part of the offender. We might expect the ceremony to cause shame-particularly if the offender identifies with the community that is denouncing him. But to lower the offender's

it'll make them safer . . . but it's also a way of expressing outrage"); Scarlet Bumper, Time 52 (June 17, 1985) (quoting judge who uses shaming penalties: "humiliation as punishment is valid"); Carol-Faye Ashcraft, DUI Offenders on Display, Orlando Sentinel 6 (July 8,1990 ) (available in LEXIS) (criticizing fines because they do "not mean much" while praising shaming penalties on the ground that "public humiliation" is "more sobering"); Editorial, Punishment, Cin Enq at A10 (cited in note 169) (judge who ordered man convicted of assault to permit wife to spit in his face: "It's my way to impress upon him the humiliation of the act.").

${ }_{184}$ See John Rawls, $A$ Theory of Justice $444-45$ (Oxford 1972); Gabriele Taylor, Pride, Shame, and Guilt 53-59, 64-65 (Oxford 1985).

185 See Franklin E. Zimring and Gordon J. Hawkins, Deterrence: The Legal Threat in Crime Control 215-16 (Chicago 1973) (describing studies finding that imprisonment is status enhancing within gang culture).

${ }^{186}$ See generally Martha Craven Nussbaum, Shame, Separateness, and Political Unity: Aristotle's Criticism of Plato, in Amélie Oksenberg Rorty, ed, Essays on Aristotle's Ethics 395, 399-400, 403-04 (California 1980) (arguing that failure to experience shame when a good person would is a vice).

187 See Harold Garfinkel, Conditions of Successful Degradation Ceremonies, 61 Am J Sociology 420, 422-23 (1956). 
social status within that community, it is enough that the affliction convey disapproval in terms that its members understand.

Whether particular afflictions have this effect obviously depends on the conventional signification of different actions within particular communities. Such understandings, moreover, are richly variant. ${ }^{188}$ This is part of the reason that shaming penalties assume such diverse forms.

Insofar as shaming penalties do successfully convey condemnation, substituting them for imprisonment does not invariably offend widespread expressive sensibilities. Accordingly, it should be politically acceptable to punish a wide array of offenses with shaming alone.

Indeed, the political acceptability of shaming penalties as an alternative sanction is nearly an established fact. Public opinion studies suggest that the public is prepared to endorse such penalties with enthusiasm, provided it can be shown that they really work. ${ }^{189}$ The actual behavior of judges and other democratically accountable officials backs up this finding. The use of such sanctions can only be expected to widen as their notoriety grows.

\section{B. Shaming Anxieties}

Showing that shaming penalties are likely to be a politically acceptable alternative to imprisonment does not, in and of itself, show that they are appropriate criminal punishments. Members of the public insist that punishments express appropriate condemnation, but they also expect them to do an adequate job in protecting them from criminality. They also demand (or at least ought to demand) that punishments be consistent with desert, equality, and other values.

I will now address a number of important issues relating to the moral acceptability of shaming penalties. I will argue that the same properties that make shaming penalties express appropriate condemnation are also likely to make them effective and just.

188 Compare John Braithwaite, Crime, Shame and Reintegration 58-59 (Cambridge 1989) (describing shaming rituals in ancient Rome, socialist China and Cuba, Crow Indian tribes, and elsewhere).

${ }^{189}$ See Doble, Crime and Punishment at 40 (cited in note 123). See also Alter and Wingert, Return of Shame, Newsweek at 22, 24 (cited in note 158) (finding majority support use of shaming penalties for certain offenses but are skeptical about effectiveness). 
1. Shame and deterrence.

a. Deterrence in general. Does shame deter criminality? The short and simple answer is that we don't know. Shaming penalties have not yet been subject to rigorous empirical evaluation.

The longer and more complicated answer is that shaming penalties should work. There may be little data on the effectiveness of shaming penalties in particular, but the ways in which criminal penalties deter in general have been carefully studied. What we know about deterrence should make us confident that shaming penalties will be reasonably effective by virtue of their character as degradation ceremonies.

Criminal penalties deter, first, by raising the cost of criminal behavior. Potential offenders refrain from committing crimes when the threat of unpleasant consequences offsets the expected gains from breaking the law.

The consequences of shaming penalties are extremely unpleasant. Those who lose the respect of their peers often suffer a crippling diminishment of self-esteem. ${ }^{190}$ Moreover, criminal offenders are as likely to be shunned in the marketplace as they are in the public square, leading to serious financial hardship. ${ }^{191}$ Indeed, some studies suggest that the prospect of public disgrace exerts greater pressure to comply with the law than does the threat of imprisonment and other formal sanctions. ${ }^{192}$ It stands to reason, then, that shaming penalties, which abstract disgrace from the afflictive dimension of formal sanctions, should compare favorably with imprisonment as a deterrent.

Second, criminal penalties deter through preference formation. Effective punishments instill aversions to criminality that make it unnecessary to threaten most persons with sanctions for lawbreaking. ${ }^{193}$ As I have discussed, the law "moralizes"

190 See Peer Hultberg, Shame-A Hidden Emotion, 33 J Analytical Psych 109, 116-17 (1988) (noting that shame "gives rise to a feeling of humiliation and utter worthlessness," and to "fears of abandonment"). Compare Rawls, Theory of Justice at 440 (cited in note 184) (arguing that self-esteem depends on "finding our person and deeds appreciated and confirmed by others who are likewise esteemed and their association enjoyed").

${ }_{191}$ See John Lott, Jr., An Attempt at Measuring the Total Monetary Penalty from Drug Convictions: The Importance of an Individual's Reputation, 21 J Legal Stud 159 (1992).

${ }^{192}$ See Charles R. Tittle, Sanctions and Social Deviance: The Question of Deterrence 196-99, 320-21 (Praeger 1980); Grasmick and Green, 71 J Crim L \& Criminol at 334 (cited in note ); Braithwaite, Crime, Shame, and Reintegration at 69-70 (cited in note 188); Gibbs, 14 Crim L Bull at 44-45 (cited in note 54).

${ }^{193}$ See text accompanying notes $48-49$. 
through three different mechanisms: preference adaptation; belief-dependent dispositions; and goodwill. ${ }^{194}$ Shaming penalties should engage all three.

Shaming is likely to trigger preference adaptation precisely because it condemns. Like imprisonment, shaming penalties unambiguously mark the offender's behavior as contrary to community moral norms. Thus, they send a clear signal about the types of preferences well formed persons should and shouldn't have.

Shaming should also reinforce belief-dependent propensities to obey the law. It is well documented that a person's disposition to follow the law can be overridden by a belief that others whom he respects view the law as unworthy of obedience. ${ }^{195}$ Because they dramatically underscore the disgrace of lawbreaking, shaming penalties assure citizens that society regards compliance as a virtue.

Finally, shaming penalties draw on and reinforce the goodwill of the law. Citizens are more inclined to obey particular laws, whether or not they match their moral convictions, when they believe that the system of criminal justice as a whole accords with their values. ${ }^{196}$ Shaming penalties are more likely to promote this sort of confidence in the law than are fines or community service, which (I have argued) convey ambivalence about the moral character of the behavior being condemned.

The endogenous relationship between preferences and the social meaning of punishments has been largely disregarded by economists. Cooter's model, for example, examines the respective deterrent effects of "prices" and "sanctions" without considering whether the choice between them can influence the value that persons attach to legally regulated outcomes. ${ }^{197}$ If we assume, however, that stigmatizing penalties do in fact instill aversions to the forbidden behavior, ${ }^{198}$ then a penalty that merely prices

194 See text accompanying notes 50-57.
195 See note 54 and accompanying text.
196 See text accompanying notes $56-57$.
197 See Cooter, 84 Colum L Rev at $1526-30,1548-50$ (cited in note 117 ). The same can
said of Calabresi and Melamed's analysis of the respective regulatory effects of properbe said of rules, liability rules, and inalienability rules. See Guido Calabresi and A. Douglas Melamed, Property Rules, Liability Rules, and Inalienability: One View of the Cathedral, 85 Harv L Rev 1089, 1124-26 (1972).

193 As Bentham, at least, did:

A punishment may be said to be calculated to answer the purpose of a moral lesson, when, by reason of the ignominy it stamps upon the offence, it is calculated to inspire 
(say, a fine) will be a less effective deterrent than one that sanctions (say, a shaming penalty), even if the two penalties impose the same level of disutility; for in that case, a community that sanctions rather than prices will have fewer members who value the conduct enough to make breaking the law worthwhile.

These are, to be sure, conjectures, but they are at least modestly supported by experience to date. Maryland authorities, for example, report a dramatic reduction in the recidivism rate of juvenile offenders required to participate in apology rituals. ${ }^{199}$ Officials in La Mesa, California, likewise maintain that fewer prostitutes can be found on the city's streets since the city began publishing the names of men convicted of soliciting. ${ }^{200}$ Much empirical work remains to be done, but these perceptions, combined with the congeniality of shaming to the recognized mechanisms of deterrence, are certainly enough to justify further experimentation.

b. Optimal deterrence. It's one thing to show that shaming penalties deter; it's another to show that they deter in the right amount. Compared to imprisonment, shaming penalties don't seem to admit of gradations in severity. Whereas time behind bars can be infinitely divided, disgrace (it might seem) comes in only one basic amount. ${ }^{201}$ The fixed disutility of shame might be thought to be too big for certain offenses, particularly regulatory and white-collar crimes, the excessive punishment of which can chill socially desirable conduct. ${ }^{202}$ For others (including many common crimes), it might seem too small to discourage potential offenders from offending.

This concern, however, turns out to be overstated. To begin, there is good reason to think that shaming penalties impose less

the public with sentiments of aversion towards those pernicious habits and dispositions with which the offence appears to be connected; and thereby to inculcate the opposite beneficial habits and dispositions.

Bentham, Principles of Morals and Legislation at $339 \mathrm{n} 181$ (cited in note 39).

199 See Alter and Wingert, Return of Shame, Newsweek at 21 (cited in note 158).

200 Id at 24.

201 In theory, there should be ways to modulate the disutility of shaming penalties. For example, the level of publicity surrounding them could be varied. Moreover, disutility probably varies across the different forms of shaming; many forms of self-debasement are probably more unpleasant than most forms of stigmatizing publicity. These devices notwithstanding, however, it seems fair to assume that shaming penalties are less subject to gradation than either prison sentences or fines.

${ }_{202}$ See generally Dan M. Kahan, Lenity and Federal Common Law Crimes, 1994 S Ct $\operatorname{Rev} 345,400-02$. 
disutility than even relatively short terms of imprisonment. Generally speaking, the largest contribution to stigma comes from the fact of criminal conviction itself, whatever punishment is subsequently imposed. ${ }^{203}$ Thus, substituting shaming for imprisonment only reduces severity by subtracting the afflictive elements of incarceration. This is no doubt why offenders typically opt for shame over prison when given the choice. ${ }^{204}$ Because shaming penalties hurt less than imprisonment, it is implausible to think that substituting the former for the latter will aggravate the problem of overdeterrence.

These same considerations might bolster the anxiety that shame underdeters, but that problem is easily remedied. Where it is perceived that shame, by itself, is insufficient, a shaming penalty can be supplemented with other sanctions, including short terms of imprisonment, fines, and community service. ${ }^{205}$ Adding the conventional sanctions to shame reintroduces variability in punishment. And adding shame to the conventional punishments allows society to reduce its total reliance on imprisonment and thereby realize substantial savings in resources. ${ }^{206}$

${ }^{203}$ For example, lost income following imprisonment-an important measure of stigma-far exceeds the monetary loss associated with the formal penalty and varies only slightly with the severity of any term of imprisonment. See Lott, $21 \mathrm{~J}$ Legal Stud at 176, 183-84 (cited in note 191); Lott, 30 Econ Inq at 584, 597, 604 (cited in note 108). Indeed, for many offenders, the disutility associated with being subject to the criminal process itself generally exceeds the disutility of the formal sanction. See Malcolm M. Feely, The Process is the Punishment: Handling Cases in a Lower Criminal Court 199-243 (Russell Sage Foundation 1979).

${ }^{204}$ See Mathews, Freedom, Wash Post at A3 (cited in note 181). According to one defense attorney, offenders throughout New Hampshire requested shaming sanctions after a judge ordered the attorney's client to run newspaper ads announcing his conviction for sexual assault. E-mail from Michael J. Iacopino to Dan M. Kahan (July 11, 1995) (on file with U Chi L Rev).

${ }^{205}$ See Part III.C (arguing that adding shame removes the expressive impediments to use of fines and community service).

206 A related anxiety is that the availability of shame will cause society to invest excessively in punishment. Shaming costs much less than imprisonment; indeed, it arguably enriches society by gratifying the public demand for ridiculing wrongdoers. Once shaming takes hold, then, a community might begin to punish conduct that it couldn't have afforded to punish when imprisonment was the only politically acceptable option. This is an effective argument against shaming, however, only if we assume that shame will tempt a community to punish what it shouldn't view as criminal; if the underlying conduct is in fact socially undesirable, then reducing the cost of deterring it always increases social wealth. Should we worry that shame will tempt the community to enact bad laws? We probably shouldn't, at least if we adopt a conventional wealth-maximizing criterion of value. Democratic politics might not generate perfectly efficient outcomes, but it's hard to imagine a better mechanism for assuring that criminal laws create more wealth than they consume. See generally Frank H. Easterbrook, Criminal Procedure as a Market System, $12 \mathrm{~J}$ Legal Stud 289, 299-308 (1983) (defending reliance on discretion of democratically 


\section{Shame and community.}

My assessment of the deterrent effect of shaming penalties conflicts with that of many other criminal law theorists. Morris and Tonry, for example, dismiss "punishments designed only to stigmatize" as "more romantic than real in the urban agglomerations where crime flourishes."207 Toni Massaro argues that shame is likely to prove impotent because criminal offenders do not generally "fear social disapproval." ${ }^{\text {"208 }}$ These objections are unduly pessimistic.

Shame might not be the same force that it used to be. Anthropologists, for example, like to contrast modern, individualist societies with premodern "shame cultures," in which communal attachments were so central to individual identity that loss of face could be literally self-destructive. ${ }^{209}$ Indeed, the perceived inefficacy of shaming played a critical role in the shift from corporal punishment to imprisonment in nineteenth-century America. ${ }^{210}$

But it would be a mistake to infer from this that modern social conditions have vanquished shame altogether or even that they are inexorably at war with it. Rather as conditions change the opportunities for shame ebb and flow. ${ }^{211}$ The breakdown of pervasive community ties at the outset of the industrial revolution may have vitiated the stake that many individuals had in social status; but the proliferation of new civic and professional communities-combined with the advent of new technologies for disseminating information-has at least partially restored it for many others. ${ }^{212}$

accountable decision makers over legal rules as a device for generating efficient outcomes in criminal law).

207 Morris and Tonry, Between Prison and Probation at 5 (cited in note 3).

${ }^{208}$ See Toni M. Massaro, Shame, Culture, and American Criminal Law, 89 Mich L Rev 1880, 1919 (1991).

209 See, for example, Ruth Benedict, The Chrysanthemum and the Sword: Patterns of Japanese Culture 222-25 (Riverside 1946) (distinguishing between "shame cultures," which rely on external sanctions, and modern "guilt cultures" based on internalized morality); Taylor, Pride, Shame, and Guilt at 54-57 (cited in note 184) (In a "shame culture," loss of honor means loss of identity.). Some scholars, however, dispute the claim that "shame" plays substantially different roles in Western industrialized cultures and in preindustrialized or non-Western ones. See, for example, Milton B. Singer, Shame and Guilt Cultures, in Gerhart Piers and Milton B. Singer, Shame and Guilt: A Psychoanalytic and a Culture Study (Norton 1971).

${ }_{210}$ See text accompanying notes 80-83, 90-91.

211 See John Braithwaite, Shame and Modernity, 33 Brit J Criminol 1, 13 (1993).

212 Braithwaite, Crime, Shame and Reintegration at 153 (cited in note 188) (" $[\mathrm{C}]$ ommunity lost is community regained in other ways: the modern urbanite is more 
Consider, for example, a corporate executive who is deciding whether to bribe a public official or to dump toxic wastes. He might not care that much what an auto mechanic in a remote part of town will think of him if he is caught and word of his offense broadcast to the community at large. But he probably cares a lot about what his family, his colleagues, his firm's customers, his neighbors, and even the members of his health club think. The prospect of being disgraced in their eyes thus continues to furnish a strong incentive-psychological, economic, and otherwise - to avoid criminality. ${ }^{213}$

The idea that shame won't work because criminals are typically unconcerned with how they are perceived is even less persuasive. The argument is remarkably close to the fallacy that the commission of crimes proves that punishments don't deter. ${ }^{214}$ Even if we are convinced that no penalty of any size would deter crimes by a certain class of individuals, it would make sense on deterrence grounds to punish those individuals if doing so could be shown to induce sufficient compliance by others. Likewise, shaming even the shameless would be justified on deterrence grounds if we believed that the threat of like treatment would exert a sufficiently large regulatory effect on the general population of potential offenders. ${ }^{215}$ Empirical research on how much most persons value their reputation gives us firm grounds to believe exactly that. ${ }^{216}$

densely interdependent with a collection of associates and authority figures in the workplace than was the farm lad.").

${ }^{213}$ The experience of jurisdictions that have used shaming penalties confirms their power to deprive offenders of valued standing in the community. Offenders required to publish self-debasing newspaper advertisements often move to escape the stigma. See Knobelsdorff, Choosing, Christian Sci Monitor at 3 (cited in note 170). To prevent the option of relocation from vitiating deterrence, Oregon authorities now require offenders to republish their advertisements in their new communities. Id.

${ }^{214}$ See Massaro, 89 Mich L Rev at 1918 (cited in note 208) ("An offender has demonstrated her imperviousness to the relative cost of public shaming by committing the act in question.").

215 In addition, shaming penalties-like other degradation rituals-are likely to have a spillover effect, stigmatizing not just offenders but their family members and friends. See, for example, Rosenstiel, Some Crooks Get a Choice, LA Times at 14 (cited in note 177) (quoting proponent of stigmatizing publicity: "I want people to read the ads and say, "Gee, there is [ ] Freda's second cousin in the paper, and it says he's been doing this stuff for years." ). These persons will often value their reputations even when the offender does not value hers. Accordingly, the threat of shaming gives a potential offender's intimate associates-who are probably in the best position to shape her character and control her behavior-an incentive to assure her obedience to law.

${ }_{216}$ See notes 190-92 (identifying studies linking threat of public disgrace to compliance with law). Compare Alter and Wingert, Return of Shame, Newsweek at 21 (cited in note 158) (Sixty-two percent of Americans think most people would feel shame if it were known 
A narrower claim would be that entire classes of potential offenders are unlikely to be deterred from certain crimes by the threat of shame. ${ }^{217}$ Even this view, particularly to the extent that it rests on presuppositions about the different value attached to reputation within different ethnic or racial subcommunities, is overstated. ${ }^{218}$ It is plausible, though, to think that shaming will be less effective for offenses typically committed by the poor and disaffected than for offenses more likely to be committed by middle class or affluent individuals, for whom the cost of stigma is likely to be the largest.

At most, however, this consideration gives us a reason to be selective about the use of shaming penalties, not to reject them wholesale. Even if all potential cocaine dealers and muggers are shameless, it seems unlikely that all potential drunk drivers, embezzlers, statutory rapists, tax evaders, and toxic-waste dumpers are. Why throw away the savings that could be achieved by shaming rather than imprisoning these offenders?

\section{Shame and stigma.}

Critics argue (somewhat inconsistently) that shaming penalties are likely to be ineffective deterrents not only because they hurt offenders too little but also because they hurt them too much. Such penalties aim to disgrace the offender. Once a person has been so stigmatized, his propensity to commit offenses (it is claimed) is no longer held in check by the prospect that he will lose social status. In fact, at that point, the shamed individual can maintain self-respect only by turning to deviant subcommunities that value and thereby reinforce the very traits for which he has been condemned by society at large. ${ }^{219}$ Shame,

that they had committed adultery, 73 percent if it were known that they had struck a child, and 69 percent if it were known that they drove while intoxicated.).

${ }^{217}$ Compare Wheeler, Mann, and Sarat, Sitting in Judgment at 144-48 (cited in note 116) (reporting finding that federal judges view disgrace of conviction as sufficient punishment for many white-collar offenders but insufficient for many common ones because of differential in value of reputation between two groups).

${ }_{218}$ See Sheldon X. Zhang, Measuring Shaming in an Ethnic Context, 35 Brit J Criminol 248 (1995) (concluding that shaming is as central within African-American families as in Asian-American ones).

${ }_{219}$ See Massaro, 89 Mich L Rev at 1919 (cited in note 208). For general discussions of ways in which stigmatization reinforces delinquency, see Edwin M. Schur, Radical NonInterventions (Prentice Hall 1973); Ian Taylor, Paul Walton, and Jock Young, The new criminology: for a social theory of deviance (Routledge \& Kegan Paul 1973). 
the critics maintain, is therefore a self-defeating strategy for preventing criminal behavior. ${ }^{220}$

This claim, however, faces a massive baseline problem. The alternative to shaming penalties, at least for serious offenses, is imprisonment. Imprisonment likewise satisfies the conditions of successful degradation ceremonies ${ }^{221}$ precisely because liberty deprivation is such a potent symbol of moral condemnation in American society. Indeed, casual observation and common sense suggest that persons who are imprisoned are more likely to be shunned and driven into criminal subcultures than those who are subjected to shaming penalties. ${ }^{222}$ Unless they are prepared to reject the use of imprisonment on the same ground, the critics cannot persuasively challenge shaming penalties based on their stigmatizing effect.

In addition, the critics overlook how stigma can be ameliorated. John Braithwaite has defended the practice of combining shaming with "reintegration ceremonies," which restore status to the offender after marking his conduct as deviant. ${ }^{223}$ Some forms of shaming used in American jurisdictions, particularly apology rituals, seem geared toward such an outcome. ${ }^{224}$

But even if we assume that shaming penalties are uniquely and irreparably stigmatizing, the critics have failed to demonstrate that they are self-defeating. It is fair to assume that the loss of status associated with shaming reduces the costs of future criminality, perhaps making imprisonment the only credible deterrent to subsequent offenses. ${ }^{225}$ But, the question, from a

220 See Massaro, 89 Mich L Rev at 1924 (cited in note 208).

221 See text accompanying notes 187-88.

222 Empirical evidence, too, shows that loss of postconviction income-one proxy for the willingness of law-abiding members of society to associate with a punished offender-is positively correlated with the length of any term of imprisonment. See Lott, 30 Econ Inq at 597 (cited in note 108).

${ }_{223}$ Braithwaite, Crime, Shame and Reintegration at 54-68 (cited in note 188). See also John Braithwaite and Stephen Mugford, Conditions of Successful Reintegration Ceremonies, 34 Brit J Criminol 139 (1994) (Study of "community conferences" for juvenile offenders suggests fourteen characteristics of successful reintegration ceremonies.); Toni Makkai and John Braithwaite, Reintegrative Shaming and Compliance with Regulatory Standards, 32 Criminol 361 (1994) (Nursing home inspectors who take a reintegrative shaming approach are best able to elicit compliance.).

${ }_{224}$ See text accompanying notes 171-72.

225 Consider, however, Lott's interesting finding that offenders suffer greater income reduction after their second or third convictions for certain common offenses-including theft, larceny, and drug crimes-than they do after their first. Lott, 30 Econ Inq at 597 (cited in note 108); Lott, $21 \mathrm{~J}$ Legal Stud at $167 \mathrm{n} 21$ (cited in note 191). This is tangible evidence that a single conviction does not completely vitiate the stake that an individual has in protecting her reputation. 
general deterrence point of view, is not what effect shaming penalties have on the behavior of convicted offenders ex post, but what effect such penalties have on the behavior of potential offenders ex ante. Shaming penalties might be extremely effective in regulating behavior and shaping preferences precisely because the prospect of a permanent loss of status is so dreadful. If so, then any reduction in recidivism associated with lessening shame might well be offset by an increase in first-time offenses.

The critical point, however, is that the net deterrent and recidivist effects of shaming can't be resolved by a priori theorizing. The question requires, and deserves, the kind of empirical assessment that a dogmatic opposition to shaming penalties would only obstruct.

\section{Shame and cruelty.}

Is shaming cruel? ${ }^{226}$ Shame works, if it does, because the respect of one's peers is essential to a person's well-being. Can it be just to take this good away from someone? For some critics, the answer is no. ${ }^{227}$

But again, identifying the proper baseline disposes of the objection. However cruel shaming is, imprisonment is much worse. It expresses at least as much condemnation, and it adds a grotesque variety of indignities that shaming cannot hope to rival.

If given the choice, most convicted offenders would likely prefer shaming penalties to even short terms of imprisonment. ${ }^{228}$ That by itself is not sufficient to justify shaming or any

226 I consider the issue of "cruelty" as a moral, rather than a constitutional, question. Although the doctrine is exceedingly indeterminate, it seems fairly obvious that shaming penalties are not "cruel and unusual" for purposes of the Eighth Amendment, particularly when the alternative is imprisonment. Many courts have so concluded. See, for example, Goldschmitt v State, 490 S2d 123, 125-26 (Fla Dist Ct App 1986) (DUI plates); State $v$ Bateman, 95 Or App 456, 771 P2d 314, 318 (1989) (sign on property of sex offender); People v Letterlough, 205 AD2d 803, 613 NYS2d 687, 688 (1994), rev'd on other grounds, 86 NY2d 259, 631 NYS2d 105 (1995) (DUI plates); Lindsay v State, 606 S2d 652, 657 (Fla Dist Ct App 1992) (newspaper advertisement as condition of probation for man convicted of drunk driving); Ballenger $v$ State, $210 \mathrm{Ga}$ App 627, 436 SE2d 793, 794-95 (1993) (stigmatizing bracelet for DUI); People v McDowell, 59 Cal App 3d 807, 130 Cal Rptr 839, 84243 (1976) (tap shoes for convicted purse snatcher). See also United States v Clark, 918 F2d 843, 847-48 (9th Cir 1990) (Order to publish apology for perjury does not violate First Amendment.). Compare State v Burdin, 1994 Tenn Crim App LEXIS 852, *11-14, appeal granted May 8, 1995 (finding order to place sign warning of conviction for sexual assault of a minor did not violate First Amendment but was not adequately supported by record).

${ }^{227}$ See, for example, Massaro, 89 Mich L Rev at 1942-43 (cited in note 208).

${ }^{228}$ Many do make exactly this choice. See note 204 . 
other alternative sanction; a society can have lots of reasons for overriding offenders' choices on what forms of punishment they should receive. But it is more than paradoxical-it is either confused or disingenuous - to say that one of the reasons to disregard offenders' preferences is to spare them from cruelty.

\section{Shame and equality.}

Shaming penalties can also be challenged in the name of equality. Like fines and community service, shaming penalties are not suitable for everyone. If different classes of potential offenders attach different levels of disutility to public humiliation, ${ }^{229}$ it might be the case that the threat of shame alone is insufficient to deter certain crimes. Even more important, some offenders require incapacitation and not just condemnation. Is it fair to punish these persons with imprisonment while punishing those who commit crimes of like severity by shaming?

The meaning of "equality" here is by no means straightforward. As I argued in Part II, we can assess the equivalence of punishments along multiple dimensions. ${ }^{230}$ To indict a particular alternative sanction on grounds of equality, then, requires showing not only that it differs in some way from imprisonment but that the difference is morally relevant.

Meaning is one dimension of equivalence that clearly matters. Fines and community service, for example, don't express condemnation as clearly as imprisonment does; because condemnation is essential to punishment, imprisoning one offender while fining or ordering community service for another equally culpable one creates an objectionable form of inequality. The meaning of corporal punishment also offends equality because against the background of historically rooted social norms, this mode of discipline falsely asserts the offender's natural or social inferiority.

Shaming suffers from neither of these defects. It clearly does express condemnation; that's exactly why it is succeeding in replacing imprisonment for certain offenses. Yet shaming doesn't express false hierarchy. Shaming penalties are free of any historical association with slavery or other forms of inequality.

Indeed, the selectivity of such penalties should insulate them from hierarchical connotations. It's plausible to imagine that degradation ceremonies would acquire a hierarchical meaning if

${ }^{230}$ See text accompanying notes $84-93,113-15$. 
concentrated on groups that have traditionally been treated as socially inferior. It might also be morally objectionable to inflict loss of status on persons who have already been systematically and unjustly denied it. Shaming penalties, however, are used only for crimes for which incapacitation is relatively unimportant, such as drunk driving, white-collar offenses, larceny, nonviolent sexual assaults, and the like. ${ }^{231}$ These offenses are committed by persons of relatively diverse racial and economic backgrounds; ${ }^{232}$ indeed, from a deterrence point of view, shaming penalties are most effective against persons who have status to lose. There is thus little reason to assume that the systematic use of shaming penalties will reinforce or exploit existing sources of inequality.

Do imprisonment and shaming invariably express unequal levels of condemnation? Not necessarily. To be sure, we sometimes say that one form of affliction (say, capital punishment) reflects "more" condemnation than another (say, life imprisonment). But it seems unlikely that we say this because we have in mind some quantitative metric for measuring the level of condemnation associated with each (does capital punishment invariably cause more "disutility" than life imprisonment?); rather, we are saying that against the background of social norms, one penalty more accurately captures our assessment of the gravity of the offender's wrongdoing than does the other. Because what is really at stake, then, is the fit between the mode of punishment and shared expressive sensibilities, it is probably more accurate to say that in some circumstances different penalties express condemnation "more" or "less appropriately" rather than simply "more" or "less." And it hardly seems obvious that a shaming penalty expresses condemnation less appropriately than does imprisonment where incarceration is unnecessary for purposes of deterrence or incapacitation.

231 See text accompanying notes $173-80$.

232 In 1993, for example, over one million whites but only 130,000 African-Americans were arrested for drunk driving, and over 67,000 whites but only 18,000 African-Americans for sex offenses (excluding forcible rape and prostitution). See 1994 Statistics 388 table 4.11 (cited in note 2). Overall, whites made up approximately 67 percent of the total arrests for burglary, 65 percent of those for larceny, 57 percent of those for auto theft, and 75 percent of those for arson. See id. As of 1994, roughly 75 percent of the men in federal prisons for extortion, fraud, bribery and other white-collar offenses were white. Id at 559, table 6.39. These numbers do not show that these offenses are committed by members of different racial groups in proportion to their representation in the general population; but they do show that shaming, if used on a widespread basis for such offenses, would be unlikely to be viewed as a device for visiting degradation only on African-Americans. 
There are other dimensions, however, along which shaming is clearly not equivalent to imprisonment. At a purely formal level, shaming simply treats offenders differently from those who are imprisoned. Moreover, imprisonment might be more painful. Although it is difficult to measure the painfulness of afflictions apart from their regulatory effects, it seems plausible to think that even short terms of imprisonment are more painful than dramatic shaming rituals, especially insofar as offenders seem to prefer shaming when given the choice.

But do these inequivalencies matter? Some retributivists attack fines and community service on "same treatment" and "equal suffering" grounds. Their criticisms, however, turned out to be unconvincing in those contexts, ${ }^{233}$ and they are no more convincing in this one.

The "same treatment" conception of equality is uncompelling. Formal equality alone has no force; differences in treatment must offend substantive values before they matter. Mere sameness of treatment, abstracted from all else, is not a value anyone cares about.

Suffering-abstracted from all else-should not be a value anyone cares about. The problem with fines and community service, in the end, is not that they fail to impose suffering equal in amounts to imprisonment, but that they fail-in whatever amounts they are imposed-to express appropriate condemnation. If we are satisfied that shaming penalties do express appropriate moral condemnation-and that such penalties generate satisfactory consequences-why should we reject them simply because they don't hurt one offender as much as imprisonment hurts another? The idea that the justice of punishment should be measured in the currency of pain is the form of retributivism that has the least to recommend it.

\section{Making the Conventional Alternatives Shameful}

The political unacceptability of conventional alternative sanctions arises from a conflict between public sensibilities and the social meaning of different forms of affliction. The most promising way to overcome this barrier to reform, I have argued, is to adapt alternative sanctions to dominant expressive sensibilities. One means of doing that is to identify new alternatives, like shaming penalties, that unambiguously express condemnation. 
But another approach is to reform conventional penalties, like fines and community service, so that they, too, satisfy rather than disappoint the public demand for condemnation. The primary advantage of this approach is that it harnesses the known deterrent benefits of these punishments. The question, then, is whether self-conscious legal reform can alter the social meaning of the conventional alternatives to imprisonment.

Shaming can be used for this purpose as well. By combining fines with shame, and by suffusing community service with it, the law creates a context in which these sanctions unambiguously denote condemnation.

\section{Shameful fines.}

American jurisdictions have traditionally been reluctant to substitute fines for imprisonment. The reason is that fines do not unambiguously express appropriate moral condemnation; when used in lieu of imprisonment, fines often convey that society is willing to license the offender's behavior. ${ }^{234}$

The reluctance to fine, however, disappears when fines are used in conjunction with imprisonment. ${ }^{235}$ Again, the best explanation is expressive. Even short terms of imprisonment unambiguously signal society's condemnation. Against this background, the inference that a supplemental fine is meant to "price" rather than "sanction" a wrongdoer's conduct cannot be maintained. ${ }^{236}$

Shaming penalties can achieve the same effect. Where the law imposes shame, there is no longer any doubt that the political community means to condemn the offender's conduct. In this context, the fine, too, condemns rather than condones, while presumably magnifying deterrence. ${ }^{237}$

234 See text accompanying notes 117-29.

${ }^{235}$ See generally Hillsman, Sichel, and Mahoney, Fines in Sentencing at 162-63 (cited in noted 2).

${ }^{236}$ See text accompanying notes 117-21.

237 The United States Sentencing Commission has arguably taken this approach already. At the same time that it issued guidelines enhancing the fines for corporate criminality, the Commission conferred the power to order a convicted "organization, at its expense and in the format and media specified by the court, to publicize the nature of the offense committed, the fact of conviction, the nature of the punishment imposed, and the steps that will be taken to prevent the recurrence of similar offenses." United States Sentencing Commission, Guidelines Manual, § 8D1.4(a) (Nov 1994). According to the former Deputy Chief Counsel for the Commission, the purpose of this provision was to authorize "shaming' [of the] corporation," thereby "adding a further threat of harm to a firm's reputation . ..." Jeffrey S. Parker, Rules without . . . : Some Critical Reflections on the Federal Corporate Sentencing Guidelines, 71 Wash U L Q 397, 430 (1993). 
This is not to say that a shaming penalty accompanied by a fine is the full equivalent of a short term of imprisonment accompanied by a fine. Disparities in treatment and possibly in pain still persist. However, if, as I've argued, the real problem for fines is that they fail (by themselves) to express appropriate moral condemnation, then these persisting inequivalencies should pose no political or moral obstacle to substituting fines and shame for imprisonment on a selective basis.

\section{Shameful service.}

The meaning of community service is subject to similar reform. What makes this form of discipline a politically unacceptable alternative to imprisonment is that it conflicts with the positive connotations associated with good works; the resulting dissonance not only fails to express condemnation, but in fact conveys a false assessment of the value of nonpunitive public service, the character of the persons who perform it, and the worth of those whom it benefits. ${ }^{238}$ To overcome these problems, it is necessary to divorce punitive community service from the social norms that give nonpunitive community service its positive meaning.

This can be done by infusing punitive community service with shame. One way to accomplish this result is to make disgrace a dramatic and visible component of such penalties. Some jurisdictions, for example, require persons engaged in community service to wear clothing that unmistakably identifies them as criminal offenders. ${ }^{239}$ This form of stigmatization not only avoids confusion about the status of such offenders, but also supplies a dramatic symbol of deviance that apparently erases the dissonance associated with community service penalties.

A second way to infuse this sanction with shame is to order offenders to perform services that unambiguously denote humiliation. Some tasks, such as manure shoveling, ${ }^{240}$ fit this descrip-

238 See text accompanying notes 140-51.

${ }^{239}$ See, for example, Nev Rev Stat $\S 484.3792(1)(a)(2)$ (1991 \& Supp 1994) (drunk drivers); Susan Brenna, Justice in my Backyard, Newsday 46 (Jan 18, 1994) (available in LEXIS) (New York City shoplifters sentenced to perform cleanup tasks wearing "Community Court" vests). Compare Mary A. Johnson, Council Gears Up for Fight Against Crime, Chi Sun-Times 28 (Oct 5, 1994) (reporting proposal to require parents of juvenile curfew violators to wear distinctive orange vests while performing community service); Carolyn Click, Republicans Unveil New Volleys in War on Drugs, UPI Wire (Apr 21, 1989) (available in LEXIS) (reporting gubernatorial candidate's proposal to require drug offenders to perform community service in "stigmatizing" t-shirts).

${ }^{240}$ See Margaret Mallon, Felon Woes of Texas, Scottish Daily Record 7 (Jan 12, 1995) 
tion because they are believed intrinsically repulsive. But even services that are not inherently distasteful can acquire degrading connotations if strictly confined to criminal offenders. In one municipality, only criminal offenders work in the community garden; because this is a matter of common knowledge, performing such services becomes a stigmatizing form of self-debasement. ${ }^{241}$

Finally, simply changing the name of community service would likely ease some of the tension between this mode of discipline and public expressive sensibilities. A label like "shameful service" would underscore the law's commitment to distinguishing the types of affliction used to mark the disgrace of criminals from the forms of public service that ought to entitle citizens to admiration and respect.

\section{CONCLUSION}

My objective in this Article was twofold: to make sense of the political unacceptability of the conventional alternatives to imprisonment and to defend the expressive theory of punishment.

The dominant position of imprisonment is usually attributed either to the public's ignorance or to its appetite for human suffering. My analysis suggests a more complicated and less disturbing explanation: imprisonment is expressively superior to its conventional rivals. The public expects punishment not only to deter crime but to express appropriate moral condemnation. Because of the value of liberty in our culture, imprisonment unequivocally conveys society's denunciation of wrongdoers. The conventional alternatives, however, express condemnation much more ambivalently. Fines, when used in lieu of imprisonment, often imply that society is merely pricing, not sanctioning, offenders' behavior. Community service seems to suggest that society doesn't sincerely believe the offender to be vicious, or, even worse, that it doesn't genuinely respect the virtue of those who voluntarily serve the public. Whatever equivalence there

(available in LEXIS) (reporting that Texas judge sentenced a thief to clean stables of mounted police). See also Editorial, Paying a Debt to Law-Abiding Society, Atlanta Const A16 (Sept 9, 1994) (endorsing a proposal to require certain offenders to pick up trash, clean toilets at sports stadium, and engage in other activities that involve "public humiliation"); Ashcraft, DUI Offenders on Display, Orlando Sentinel at 6 (cited in note 183) (trash collection).

${ }^{241}$ See Stephanie B. Goldberg, No Baby, No Jail: Creative Sentencing Has Gone Overboard, A California Court Rules, 78 ABA J 90 (Oct 1992) (paraphrasing official: “[s]ince everyone working there is an offender, it's similar to wearing a badge"). 
might be between these sanctions and imprisonment along the dimensions of regulatory effect and pain, they will frequently remain incommensurable with imprisonment along the dimension of meaning. When this is so, they will be inadequate substitutes for imprisonment in whatever amount they are imposed.

But determining what different forms of affliction mean should allows us to do more than diagnose existing punishment pathologies; it should also help us find a cure. American jurisdictions can liberate themselves from their excessive reliance on imprisonment if they can identify alternative sanctions that do express appropriate condemnation. I identified shaming penalties as one possibility. These sanctions, used alone, are already proving to be a politically acceptable alternative to imprisonment for many offenses. If combined with fines and community service, moreover, these sanctions would likely dispel the expressive ambiguity that makes these sanctions politically unacceptable substitutes for imprisonment.

If I have succeeded in explaining the political unacceptability of alternative sanctions, then I have necessarily succeeded in demonstrating the value of the expressive theory. My strategy for defending the expressive theory in this essay has been more pragmatic than analytic. I have not tried to derive the expressive theory from general propositions about justice or about the function of criminal law; rather, I have tried to demonstrate the existence and utility of the expressive view by using it to account for and resolve a concrete institutional problem. If the phenomenon of social meaning is a genuine constraint on institutional reform, then no successful account of criminal law can disregard the expressive theory, whatever abstract challenges might be made to its coherence or normative desirability.

What punishments say, I have argued, is an irreducible component of what they do. For this reason, theories of punishment that disregard meaning are certain not to make any sense. 


\section{.}

. 